\title{
Helmi Järviluoma
}

\section{Mantšuriasta Perikylään: paikka ja pelimannimusiikki ${ }^{1}$}

Ruotsalainen antropologi Jonathan Friedman päätti 1970-luvun puolivälissä käydä Mekeossa Papua Uuden Guinean etelärannikolla. Paikka merkitsi hänelle lähestulkoon pyhiinvaelluksen kohdetta: Mekeo vaikutti etnografisten kuvausten perusteella hämmästyttävän autonomiselta perinteiseltä systeemiltä. Ihmetyksekseen Friedman löysi paikalta traktorin osia, moottoripyöriä ja jopa lentokoneiden moottoreita. (Friedman 1994, 4-12.)

Pelimannimusiikki kategorisoidaan usein perisuomalaiseksi. Tässä artikkelissa analysoin, mitä tämä supisuomalaisuus pitää sisällään. Löytyykö siitäkin "traktorin osia"?

Olen jo pitkään tutkinut yhtä pelimanniryhmää, Virtain pelimanneja. Tässä artikkelissa tarkastelen tämän pelimanniporukan ohjelmistoa ja teemanani on paikka ja pelimannimusiikki. Oletan, että tavalla tai toisella "paikka" tulee esiin sekä pelimannien puheissa että musiikissa. Analysoin, (1) miten ja milloin paikka tulee esiin ohjelmistoa valittaessa, ohjelmistosta puhuttaessa ja kappaleiden nimissä; sekä (2) voidaanko musiikkianalyyttisen tarkastelun perusteella sanoa, miten paikka näkyy pelimannisävellyksessä.

Kiinnitän erityistä huomiota ryhmän ohjelmiston soitetuimpaan tanssilajiin, valsseihin. Näistä olen valinnut tarkemman analyysin kohteeksi valssin Muistoja Perikylästä, jonka on säveltänyt Virtain pelimanneihin kuuluvan harmonikansoittaja, eläkkeellä oleva linja-autonkuljettaja Matti Tulijoki.

${ }^{1}$ Parhaat kiitokset Matti Tulijoelle, Pekka Jalkaselle ja Timo Leisiölle artikkelin tätä versiota koskevista kommenteista. 


\section{Globaalit ja paikalliset prosessit}

Natives, people confined to and by the place to which they belong, groups unsullied by contact with a larger world have probably never existed.

Jokainen kansanmusiikintutkijasukupolvi lienee vuorollaan pohtinut kysymystä paikallisen ja kansainvälisen suhteesta kansanmusiikissa. Nykysukupolvi allekirjoittanee mukisematta Heikki Laitisen kymmenen vuoden takaisen manifestin (1988, 4): "Meidän jokaisen elämässä on sekä perinteitä että uutta, ja näin on ollut maailman sivu, iankaikkisen kauan ja tulee olemaan maailman loppuun asti." Kansanmusiikki on aina ollut sekä kansainvälistä että paikallista (mt. 10): "Ei siinä ole mitään ristiriitaa, vaan vain dynaaminen jännite näiden kahden asian välillä."

Aivan samasta asiasta puhuu antropologi Friedman "globaalin systeemisen antropologian" nimissä. Nykyisyyttä on hänen mukaansa syytä aina tarkastella jatkuvana globaalien ja paikallisten prosessien välisenä artikulaationa. Tällöin puhe tradition keksimisestä menettää oikeastaan merkityksensä. Allekirjoitankin täysin Friedmanin ja Marshall Sahlinsin kritiikin "tradition keksimiskoulukuntaa" vastaan. Sahlinsin mukaan (1993) koulukunnan edustajat tekevät teoriassa samaa mitä imperialismi yrittää tehdä käytännössä.

Friedman haluaa yhtäältä tähdentää, että organisaatiot olisi syytä nähdä osana laajamittaisia globaaleja prosesseja. Samalla hän kuitenkin vastustaa ajatusta, että maailma olisi läpikotaisin ja homogeenisesti länsimaistunut. Tähän liittyvänä paradoksaalina esimerkkinä hän mainitsee, että tämän kirjoituksen alussa kuvatussa Mekeossa nimenomaan paikallisen tuotannon yhteys laajempiin markkinoihin säilytti perinteitä, jotka olivat kadonneet syrjäisemmiltä alueilta. Niinpä lähetysaseman ympäristön kyläryhmä noudatti hyvin perinteistä, kallista arkkitehtuuria. Sen sijaan syvemmällä saaren uumenissa, tinakattoisissa rakennuksissa asuvilla mekeolaisilla ei ollut varaa pitää yllä perinteitä. ${ }^{2}$ (Friedman 1994, 4-12.)

Parin kolmen vuosikymmenen takainen Suomen maaseutu oli autioituva, hiljenevä, mineriittipäällysteinen. Kansanmusiikin uusi tuleminen ja Kaustisen kansanmusiikkijuhlat sysäsivät liikkeelle perinteiden elvytyksen monilla muillakin elämän alueilla. Protestoitiin paikallisuuden puolesta. (Laitinen 1988, 13-13; Laitinen 1977.)

1970-luvun alussa Virrat oli muun Suomen tavoin "valumassa Itämereen".

\footnotetext{
${ }^{2}$ Tällä esimerkillä Friedman haluaa valottaa seuraavaa antropologien usein unohtamaa tosiasiaa: jos aiempi laaja ryhmien välien vaihto, sodankäyntiverkostot tai paikallinen hallinto ovat romahtaneet, yhteisöt näyttävät harhaanjohtavan autonomisilta. Paikallinen alkuperäisyys saattaakin olla tulosta kolonialistisesta hallintopolitiikasta. Näin esimerkiksi pygmit, Etelä-Amerikan intiaanit ja bushmannit itse asiassa on kudottu osaksi länsimaisen identiteetin evolutionistista draamaa. Jokaisella niistä on hyvin erilainen historia kuin niille on länsimaissa yleensä kirjoitettu.
} 
Maaseudun autioituminen on edelleen kipeä asia, mutta neljännesvuosisata sitten se oli hyvin akuuttia. Virroilla yksi aktiivisista vastarintahenkilöistä oli kansalaisopiston silloinen rehtori, Pertti Tamminen, joka teki "tilan politiikkaansa" perinteen ja historian avulla. Virtain kyliin perustettiin pelimannipiirejä, kansalaisopiston opettaja Yrjö Rajan kanssa yhteistyössä. Muita perinnepiirejä perustettiin samaten: näiden tarkoituksena oli antaa ihmisille vastarinnan resursseja estämään kiivasta maaltapakoa ja "rajusti kehittyneen teknologian sumeilematonta hyväksikäyttöä taloudellisen kasvun kiihdyttämisessä" (Tamminen 1984). Pelimannipiirit perustettiin seitsemään kylään; 17 kylään perustettiin esinevarastot ja jokaiseen kylään valittiin keräyspäälliköt, joten tärkeä esineistö saatiin pysymään "kylän rajojen sisäpuolella, kyläläisten omistuksessa ja päätäntävallassa". (Ks. tarkempi kuvaus Järviluoma 1989 ja 1990.)

Tamminen ja muut perinteen puolesta puhujat halusivat parantaa ihmisten kykyä rakentaa omaa historiaansa. ${ }^{3}$ Tamminen toimi yleensä periferian puolesta keskustaa vastaan. Hän halusi säilyttää maaseudun eläjillä samat oikeudet kuin suurten keskusten väestölläkin. Kulttuurivirtausten suuntaa hän pyrki muuttamaan vaikkapa sillä yksinkertaisella politiikalla, että tutkijoille ei anneta alkuperäisiä papereita: "täältä ei lähde ykskään paperi, sen jäljennöksiä annetaan, muttei alkuperäisiä" (TAY KPL Y 9508).

Toisaalta Virroille rakennettiin 1980-luvun alussa Perinnekylä, virtolainen erikoisuus, jonka perustamisen primus motor epäilemättä oli äsken mainittu Pertti Tamminen. Tamminen piti perinnetyötä tärkeimpänä kylille itselleen, mutta Perinnekylä tarvittiin kylämuseoiden keskusmuseoksi. Virtain keskustan lähistölle Marttisensaareen koottiin vanhoja, eri kylistä peräisin olevia rakennuksia. ${ }^{4}$ Perinnekylää voi tietyssä mielessä pitää heterotopiana. Michel Foucault keksi tämän termin kuvaamaan sellaista todellista - ei utooppista - paikkaa, jossa asettuu rinnakkain monia sellaisia tiloja, jotka eivät heterotopian ulkopuolisessa

3 Tämän voi liittää kulttuurintutkijoiden nykyisin korostamaan kysymykseen toimijuudesta ja identiteetistä: "kuinka ihmiset tekevät historiaa olosuhteissa, joita he itse eivät ole aiheuttaneet" (Grossberg 1996).

${ }^{4}$ Suunnittelutyö aloitettiin vuonna 1977 ja raivaus- ja rakennustyöt tehtiin vuosina 1980-1983. Useat kymmenet virtolaiset yhteisöt osallistuivat talkoisiin. Alueelle siirrettiin tai rakennettiin mm. kauppamakasiini, hollitalli, Monoskylän työväentalo, sauna, puuliiteri ja kokonainen kenttälinnoitusalue. Virtain seura lahjoitti Perinnekylän kaupungille 1984, joka taas myi kylän keväällä 1989 tarkoitusta varten muodostetulle yhtiölle. Koko toimintansa ajan kylä on ollut melkoisen polemiikin kohteena, mutta toiminut koko ajan. Mikontalon perinneravintola on suosittu lounaspaikka ja alueella toimii käsityöläisten pajoja. Aivan lähistölle on rakennettu Tampereen yliopiston kulttuurintutkimusasema ja Nuorisomatkailukeskus.

Ihmisten, jotka kritisoivat Perinnekylän rakentamista ja kutsuvat sitä perinnekeksinnöksi, olisi syytä muistaa, etteivät vallan tekoja ole niinkään ne, joissa jotakin luodaan "tyhjästä" vaan ne, joissa jokin tehdään tyhjäksi (vrt. Grossberg 1996, 99). Perinnekylän rakentaminen maaseudun autioitumiskriisin keskellä on interventio prosessiin, joka oli parhaillaan muuttamassa virtolaistakin todellisuutta raskaalla kädellä. 
maailmassa sovi yhteen. Heterotopiat ikäänkuin kääntävät niiden ulkopuolella olevan maailman suhteet ylösalaisin. $\mathrm{Ne}$ antavat ihmisille illuusioita tai korvaavat ulkopuolisten paikkojen epätäydellisyyttä. (op. cit. Harvey 1989; Foucault 1986; vrt. Kurikka 1995, 40.)

\section{Kuinka Perikylä soitetaan}

Terveisiä Virtailta kaikille vilppulalaisille (taputetaan) Ja tämä on Muistoja Perikylästä, siälä on semmonen Perinnekylä siälä Virroilla. Siä on muuten kauheen hyvää ruakaa, että poikekkaas sinne joskus syömään. (---) (soittavat valssin) Virtain ja Vilppulan välillä on paljo aina yhteistä semmosta kaikenlaista, minäkin olen sen yhteistoiminnan tulos. (taputetaan) Meidän kotikylään tuli seittemän emäntää Virroilta.

Tällä tavoin pelimannien johtaja esittelee Muistoja Perikylästä valssin PohjoisPirkanmaan pelimannien tapaamisessa keväällä 1989 yleisölle. Muistoja Perikylästä yhdistetään Perinnekylään joka on kuulijoille tutumpi kuin Alavuden rajan pinnassa sijaitseva, Virtain Liedenpohjan kylän perukka Perikylä.

Kappaleeseen liittyi siis 1980-90 -lukujen vaihteessa ainakin kaksi paikkakertomusta. Säveltäjän mukaan valssi on sävelletty melankolisessa hengessä kotikylän muistoista, "heikkona hetkenä". Kylässä oli viisi maataloa nevan laidalla, hallanaralla seudulla. Järveä ei ollut omassa kylässä, lapset siis kävivät uimassa muutaman kilometrin päässä Sulkavanjärvessä. Viisivuotiaana, 1930-luvun laman tiimellyksessä Matti Tulijoki vanhempineen joutui lähtemään kylästä ja muuttamaan suurempaan Liedenpohjan (aiemmin Tulijoen) kylään. ${ }^{5}$

Toisen kertomuksen mukaan Matti Tulijoki olisi säveltänyt valssin kerrattaisen Virtain pelimannien Perinnekylä-esiintymisen jälkeen. Perinnekylä on todellakin muistoja virittävä paikka, ja on kiinnostavaa, että kuulemassani narraatiossa valssi yhdistettiin Perinnekylään. Näin merkityksellistettiin pikemminkin sitä kuin pientä Perikylää, jota ei löydy kartoista vaan "vanhan kansan muistoista". ${ }^{6}$

Johtaja tuo ylläolevassa esittelyssä esiin sekä erityisen - Perinnekylän - että yhteisen (emännät). Musiikkiesityksen yhteydessä siis rakennetaan paikkojen välisiä suhteita: rajoja rakennetaan ja puretaan.

Heikki Laitinen kutsuu pelimannisäveltämistä "paikallisuuden korkeimmaksi potenssiksi". Pelimannisäveltäjät usein nimeävät kappaleet henkilön, tapahtuman tai maiseman mukaan (Laitinen 1988). Tässä mielessä Laitinen vertaa pelimannimusiikkia pohjoissaamelaiseen joikuun. Esimerkiksi Piret Peltoluoma joikasi Armas Launikselle 62 joikua. Hän joikasi oman maantieteensä: kaikki ihmiset 230 kilometrin säteellä mökistään (Laitinen 1992). Laitinen on myös kertonut -

\footnotetext{
${ }^{5}$ Puhelinkeskustelu Matti Tulijoen kanssa 4.5.1997.

${ }^{6}$ Sama.
} 
havainnollisuuden vuoksi keksityn - esimerkin pelimannista, joka nimesi kappaleensa paikallisen pankinjohtajan mukaan. Paikalliset asukkaat kuulevat kappaleessa pankinjohtajan piirteitä. Sen sijaan "me" emme voi ymmärtää kappaleesta yhtään mitään: "Kukaan ulkopuolinen ei voi tietää, miten pankinjohtaja on siinä polkassa. Sitä ei saa edes tutkimalla koskaan selville." (Laitinen 1988, 14.)

Kun Matti Tulijoki säveltää valssin Muistoja Perikylästä, voimmeko me ulkopuoliset kuulla, miten tämä virtolainen viiden savun kotikylä on kappaleessa läsnä? Onko paikan jäljittäminen Matti Tulijoen valssista ylipäätään mahdollista? Ainakin siinä on haastetta kerrakseen.

Monet antropologit ja etnomusikologit ovat vakuuttuneita siitä, että identiteetti, paikka ja musiikki kietoutuvat lähtemättömästi yhteen. (Finnegan 1989; Cohen 1993a ja b, 1994a ja b; Stokes 1994; Slobin 1993.) ${ }^{7}$ Musiikin tekeminen luo ja pitää yllä arkielämämme elettyä tilaa. Se on toimintaa, jonka kautta ihmiset löytävät sosiaalisuutensa yhä uudelleen ajassa ja tilassa. (Järviluoma 1995b.)

Musiikki ei siis vain heijasta tiloja ja paikkoja vaan se myös luo ja rakentaa niitä (Waterman 1991, 66-67; Bohlman 1991, 266-267; Stokes 1994; Frith 1996). Musiikki tarjoaa keinoja, joilla paikkahierarkioista voi neuvotella ja joilla niitä voi muuttaa.

Kuinka paikkojen väliset suhteet sitten rakennetaan musiikin tekemisessä ja musiikissa itsessään? Miten "paikalliset" ja "kansainväliset" elementit onnistutaan artikuloimaan virtolaiseksi, hämäläiseksi tai suomalaiseksi pelimannimusiikiksi? Silmätäänpä hieman Virtain pelimannien ohjelmistoa ja etenkin sen suurinta tanssilajiryhmää, valsseja, ja niiden maantiedettä. Analysoin sitä, kuinka pelimannit rakentavat valssien maantiedettä puheissaan. Sen jälkeen siirryn analysoimaan tarkemmin Perikylän valssia.

\section{Valssien maantiedettä}

Valssista harvoin puhutaan erityisenä "suomalaisen identiteetin" lippulaivana. Tangoon verrattuna valssin ongelmana on, ettei sen avulla ole helppoa erottautua naapurikansoista. Venäläiset mollivalssit, saksalais-wieniläiset valssit, bostonvalssit ja ruotsalaiset pirteät duurivalssit tuntuvat risteytyneen suomalaisessa valssissa niin, että vain sekoitus on aidosti suomalaista. Esimerkiksi sama Olle Edströmin $(1989,75)$ ruotsalaisista ruotsalaisimmaksi kuvaama Kvaknäs-valssi on myös suomalaisista suomalaisin Morjensta Manta ja ylivieskalaisista ylivieskalaisin Koppelovitun valssi.

${ }^{7}$ Tätä keskustelua olen referoinut aiemmissa yhteyksissä (ks. Järviluoma 1995 ja b; Järviluoma 1996.) 


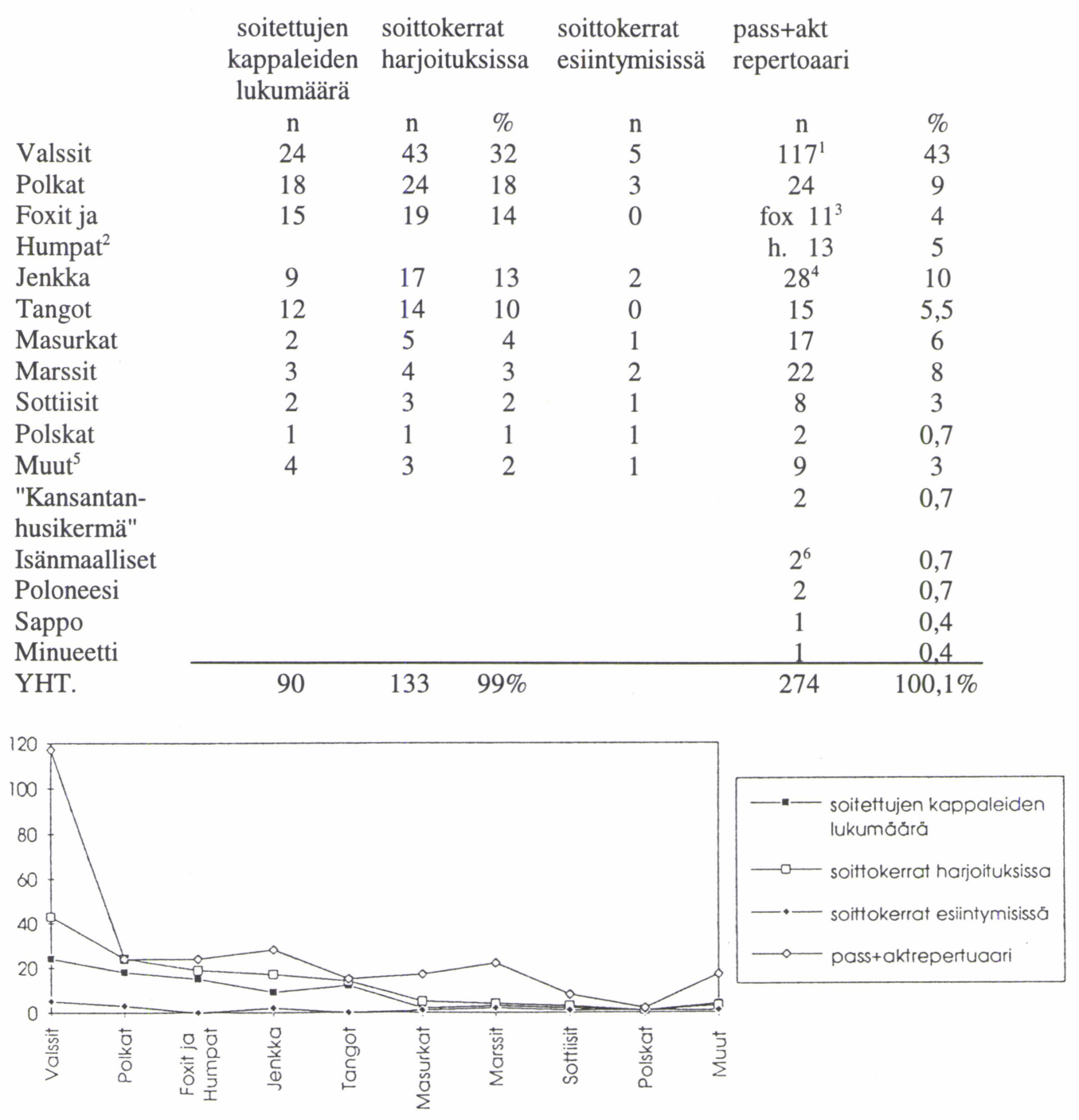

${ }^{1}$ Yksi tämän kategorian nuoteista on Pas d'Espagne. Mukana on myös Kesäpäivä Kangasalla.

${ }^{2}$ Kuunnellessani kappaleita en valitettavasti eritellyt foxeja ja humppia toisistaan. Nuoteissa pelimannit erottelivat ne periaatteessa toisistaan. Usein kuitenkin samat nuotit, vaikkapa Kullervo Linnan "Lola pien", sijaitsivat molemmissa lokeroissa. Pelimannit saattoivat myös kysyä, "soitetaanko tämä foksina vai humppana": humpan tempo oli nopeampi, foxina kappaleet soitettiin rauhallisemmin.

${ }^{3}$ Sisältää Manana -kappaleen (samba)

${ }^{4}$ Tähän lisätty yksi "tyyskä"

${ }^{5}$ Joululauluja

${ }^{6}$ Maamme-laulu ja Virtain laulu

Taulukko 1. Virtain pelimannien ohjelmisto jaettuna kappaletyyppien mukaan. 
Ruotsalaiset ovatkin omineet valssin itselleen, vaikka myös suomalaiset tuntuvat rakastavan valssia. Valssit ovat Virtain pelimannien ohjelmiston (kaiken kaikkiaan 274 kappaletta) suurin tanssilajiryhmä (117 valssia eli noin $43 \%) .{ }^{8}$ Valsseja myös soitetaan sekä harjoituksissa että esiintymisissä eniten (ks. taulukko 1). Tämä saksalaisen Ländlerin jälkeläistanssi tuntuu olevan suosiossa myös muiden suomalaisten pelimannien keskuudessa. Kun Kansanmusiikki-instituutti 1980luvun puolivälissä järjesti uusien pelimannisävellysten kilpailun, valsseja oli $35 \%$ noin 2000 saapuneesta sävellyksestä - eli lukumääräisesti eniten. ${ }^{9}$

Gunnel Biskop on tutkinut valssin varhaista historiaa Suomessa ja todennut, ettei valssi suinkaan ennen 1840-lukua ollut yksiselitteisesti paritanssi. Mies ei pidellyt yhtä naista pitkään käsivarsillaan valssin pyörteissä, vaan paria oli vaihdettu koko ajan järjestyneesti. 1700-luvulla ja 1800-luvulla oli valssi tarkoittanut esimerkiksi kontratanssiin kuulunutta pyörintää: nimityksellä tarkoitettiin usein erilaisia pyörimistapoja (Biskop 1991, 86). Ensimmäinen tieto valssin tanssimisesta Suomessa on peräisin vuoden 1800 jouluaatolta, jolloin elimäkeläinen 14-vuotias kartanonneiti Jacobina Charlotta Munsterhjelm mainitsi asiasta päiväkirjassaan. (mt. 87; Rausmaa 1981, 170; Kolehmainen 1978, 354.) ${ }^{10}$ Jo 1800-luvun kahden ensimmäisen vuosikymmenen suomalaisissa nuottikirjoissa valssi oli katrillin ohessa vallitsevin tanssityyppi.

Vanhoissa taidemusiikkisäveltäjienkin hitaissa valsseissa oli usein vain kaksi 8-tahtista repriisiä. Samaten vanhat suomalaiset valssisävelmät olivat lyhyitä, muutaman repriisin pituisia, ja nimeäminen "valssiksi", "valssikatrilliksi" tai "katrilliksi" tapahtui tanssikoreografian mukaan. Näillä nimityksillä saatettiin tarkoittaa yhtä ja samaa sävelmää. Vallitseva rytmityyppi on ollut kahdeksasosakulku (Nallinmaa 1969).

Jorma Väänänen näki vuonna 1945 julkaistussa tutkielmassaan Beobachtungen über Verbreitung und Art der Finnischen Volkswalzermelodien vaivaa todistaessaan, että valssi olisi suurelta osin tullut Suomeen lännestä (mt. 23). Hän on mm. laskenut, että 1800-luvun loppupuolen ja 1900-luvun alkupuolen kansanvalsseista $70 \%$ oli duurissa, $14,5 \%$ mollissa, moduloivia oli 14,5 ja $1 \%$ "epämääräisiä". Duuria hän piti siten luonteenomaisimpana moodina suomalaiselle valssille. Esimerkiksi A.O. Väisäsen Uhtualta vuonna 1915 keräämät harmonikkavalssit ovat poikkeuksetta mollissa; ne Väänänen kategorisoikin tutkimuksensa

\footnotetext{
${ }^{8}$ Nämä tiedot ovat vuoden 1992 tienoilta. Kopioin nuotit henkilöltä, joka lopetti piirissä soittamisen tuona vuonna. Lukuihin on lisätty muutamia kappaleita, joista saamassani pinkassa ei ollut nuotteja, mutta joiden harjoittelemista havainnoin.

${ }^{9}$ Westerholm 1995.

${ }^{10}$ Walzer-sana tuli käyttöön 1700-luvun lopulla. Alunperin hitaan ländlerin sanotaan tuolloin muuttuneen Wienissä seuratanssiksi, tempoltaan nopeaksi, kevyemmäksi ja vähemmän tömisteleväksi. Lukuisat taidesäveltäjät omaksuivat valssirytmit, ja muutenkin 1800 -luku kuului valssille.Ranskan valse musette kulki usein 6/8-tahdissa, englantilainen valssi ja boston ovat hitaita. (Ks. esim. Sachs 1933; OIMT Kolehmainen 1978, 565; Jalkanen 1992, 204.)
} 
ulkopuolelle ei-suomalaisina eli itä-karjalaisina. Samalla hän mainitsi niiden olleen lauluvalsseja. ${ }^{11}$ Syynä valssin iloisen luonteen menetykseen hän piti 1900-luvun operettimusiikin nyyhkivää mentaliteettia. (Mts. 8, 41.)

Pekka Jalkanen on sekä-että -linjan kannattaja. Hänen mukaansa valssi omaksuttiin kansan-, tanssi- ja iskelmämusiikkiin 1800-luvun alusta alkaen mm. keskieurooppalaisten salonkiorkestereiden ja venäläisten soittokuntien välityksellä.

Hän toteaa, että "Wiener-valssiin verrattuna suomalaisen tempo on hitaampi ja rakenne yksinkertaistunut kolmi- (Metsäkukkia), kaksi- (Rantakoivun alla) tai yksitaitteiseksi (Kankaan Katriina eli Kaiho-valssi)". (1992, 204). On varmaankin aivan oikein sanoa "mm." salonkiorkestereiden ja soittokuntien välityksellä, sillä valssin liikkeistä ei ole varmaa tutkimustietoa. Ei ole selviö, että suomalaisen valssin rakenne polveutuu wienervalssista.

Silmäsin Vanhoja pelimannisävelmiä -kirjan valsseja (Kolehmainen 1975). Mielenkiintoista kyllä, lukkari Lehrbackin 1840-luvun Pohjanmaalla, "etenkin Limingan pitäjässä", kuulemissa valsseissa on voittopuolisesti kolmesta kuuteen taitetta eli repriisiä. Kirjan 1860-luvulla tallennetut valssit taas muodostuvat etupäässä kahdesta repriisistä.

Tanssit ovat varmasti aina kulkeutuneet hyvin monilla tasoilla ja monin tavoin maista, maakunnista ja paikkakunnilta toiseen, eivätkä siirtymismuodot ole aina olleet yhteiskunnassa vertikaalisia vaan myös horisontaalisia (vrt. myös Hoppu 1995). Varmasti voidaan sanoa lähinnä se, että kansan- ja säätyläisten musiikki ovat olleet 1800-luvulla monella tasolla vuorovaikutuksessa keskenään. Gesunkenes kulturgut -teoria ei auta meitä kaikin osin ymmärtämään tätä historian orkesteria.

Tutkimani ohjelmiston 117 valssista 70 kappaletta kulkee (pääasiassa) mollissa (noin $60 \%$ ), duurissa 47 kappaletta. Tämä ei kuitenkaan välttämättä tue Väänäsen oletusta, jonka mukaan iloinen valssi olisi kokonaan tappiolle jäänyt intonaatio. Duurivalsseja pidetään "pirteinä", ja niitä - usein veteen liittyvine nimineen - soitetaan ahkerasti. Pelimannit itse eivät sen kummemmin erittele valsseja eri luokkiin. He tuovat ne esiin kappaleiden säveltäjien kautta tai sitovat ne eri paikkakuntiin tai kansallisuuksiin. Lähinnä analyysin tarpeita varten olenkin rakentanut valsseista taulukon (2), joka on puoliksi emisistinen, puoliksi etisistinen. Taulukosta näkyy yhtäältä, mistä päin maailmaa valssit ovat peräisin (ulkomailta yli $17 \%$ ). Harmonikkasäveltäjien valssit olen ottanut omaksi ryhmäkseen sen vuoksi, että pelimannit usein tuovat nämä säveltäjät esiin ohjelmistosta puhuessaan. Jäljelle jäävien valssien jako "iskelmiin", "kansanmusiikkiin" ja "uuteen kansanmusiikkiin" taas ei ole puoleltani mikään kannanotto näiden

${ }^{11}$ Simo Westerholm (puhelinkeskustelu 13.12.1995) onkin maininnut, että 1920-30 -lukujen vahakantisiin lauluvihkoihin kirjoitetut kappaleet usein laulettiin valssin tahtiin (Mäen reunassa pienoinen tölli, jne.). 
musiikkiluokkien välisiin suhteisiin eikä "olennaisiin" sisältöihin (tästä ks. esim. Järviluoma 1986, 151-162). ${ }^{12}$

$\begin{array}{ll}\text { suomalaiset iskelmät } & 36 \\ \text { suomalainen kansanmusiikki* } & 17 \\ \text { venäläiset } & 9,4 \\ \text { suomalainen uusi kansanmusiikki ** } & 9 \\ \text { suomalaisten harmonikansoittajien säveltämät } & 7,7 \\ \text { ruotsalaiset } & 6 \\ \text { virtolaiset } & 5,1 \\ \text { kaustislaiset } & 4,3 \\ \text { sekalaiset } & 3,5 \\ \text { englantilaiset } & 0,85 \\ \text { virolaiset } & \underline{0,85} \\ & 100 \% \\ \text { * Keräyspaikkakunta nuotissa. } & \\ \text { ** Säveltäjä nuotissa. Virtolaiset ja kaustislaiset erikseen. }\end{array}$

Taulukko 2. Virtain pelimannien valssiohjelmiston luokittelua ja prosentuaalinen jakauma. Ks. tarkemmin liitetaulukko 2. N=117.

\section{Ohjelmiston otsakkeet ja paikat}

Jo Virtain pelimannien ohjelmiston valssien otsikoista voi löytää monivivahteisia paikankategorisointeja. (Vrt. taulukko 3 ja liitetaulukko 2.) Uudemmissa pelimannisävellyksissä liikutaan kylissä - tai jopa lähiöissä - paikallisilla niemillä, järvillä, metsissä tai myös omassa maakunnassa. Mielenkiintoinen poikkeus on ilmeisesti eteläpohjalaisiin speleihin harjoiteltu Pakolaisvalssi, jonka herättämät diasporamietteet tuovat mielenkiintoisen särön tähän paikallisdiskurssiin.

Kotimaisten iskelmien otsakkeissa vilahtelevat romanttisnostalgiset paikat. Vesistöt ovat tärkeitä: liikutaan Airistolla, Koitereella, saaristossa, Äänisen aalloilla tai laineilla ylipäätään - satamaankin saavutaan. Kovalla maaperällä tapahtumat sijoittuvat metsäpirttiin tai savottaan, keinupaikalle, tunturiin tai lakeudelle. (Vrt. myös Kurkela 1989, 283-284.)

Iskelmillä on toki paljon muitakin kuin paikkoihin liittyviä nimiä: niissä on häitä ja haavoja, kaipuuta, valheita ja kiitoksia; on Katjoja ja Marushoja, suvea, nuoruutta ja särkynyttä onnea. Iskelmissä mainitut paikat näyttävät olevan

${ }^{12}$ Iskelmiin olen lukenut kansallisella tasolla tunnetut, iskelmäsäveltäjinä pidettyjen tekijöiden kappaleet; uuteen kansanmusiikkiin pelimannisävellykset, joiden säveltäjät on mainittu ja kohtaan kansanmusiikki ne nuotit, joissa vain keruupaikkakunta on mainittu tai joihin on kirjattu merkintä "kansansävelmä". 
yleisesti tunnettuja: edellä mainittujen vesistöjen lisäksi Mantšuria, Saarenmaa ja miksei Pispalakin. Uudessa kansanmusiikissa, virtolaiset pelimannisävellykset mukaan lukien, paikannimet saattavat jäädä ulkopuoliselle täysin avautumatta: missä sijaitsee Ajosjärvi? Entä Leppäsjärvi tai Ristinniemi? Toisaalta kansanmusiikissa viitataan myös maakuntiin (Pirkanmaan valssi) tai jopa Hervannan lähiöön. Paikkojen lisäksi kansanmusiikkikappaleiden otsakkeita kansoittavat Karoliinat ja Joelit, kokit ja kulkijat.

\begin{tabular}{|c|c|c|c|}
\hline & Paikannimet & Veteen liittyvät paikat & Muut \\
\hline \multirow[t]{2}{*}{ Harmonikkavalssit } & Ikaalinen & Syväjärvi & \\
\hline & Åsele & Kalajoki & \\
\hline \multirow[t]{7}{*}{ Iskelmät } & Pispala & Airisto & tunturi \\
\hline & Kangasala & Koitere & metsäpirtti \\
\hline & & Saaristo & lakeus (Pohjanmaa) \\
\hline & & satama & metsä (savotta) \\
\hline & & rantakoivun alla & Pohjola \\
\hline & & Äänisjärvi & maantie (kulkuri) \\
\hline & & Ounasjoki & \\
\hline Ruotsalaiset & Arholma & satama & Suomalaismetsät \\
\hline Sekal. & $\begin{array}{l}\text { Kangasala } \\
\text { Espanja }^{13}\end{array}$ & meri & tropiikki \\
\hline \multirow[t]{2}{*}{ Venäl. } & Mantšuria & & \\
\hline & $\begin{array}{l}\text { Karpaatit (vuo- } \\
\text { risto) }\end{array}$ & Musta meri & juoksuhauta \\
\hline $\begin{array}{l}\text { Uusi kansanmusiik- } \\
\text { ki }\end{array}$ & $\begin{array}{l}\text { Hervanta } \\
\text { Kaustinen } \\
\text { koko kylä } \\
\text { Pirkanmaa }\end{array}$ & Leppäsjärvi & metsä \\
\hline $\begin{array}{l}\text { Vanhempi kansan- } \\
\text { musiikki } \\
\text { Virol. }\end{array}$ & $\begin{array}{l}\text { Kannonkoski } \\
\text { Lempäälä } \\
\text { Saarenmaa }\end{array}$ & $\begin{array}{l}\text { Hangasjärvi } \\
\text { vene }\end{array}$ & honkamökki \\
\hline Virtolaiset & $\begin{array}{l}\text { Ristinniemi } \\
\text { Perikylä }\end{array}$ & $\begin{array}{l}\text { Ajosjärvi } \\
\text { järvi }\end{array}$ & \\
\hline
\end{tabular}

Taulukko 3.Virtain pelimannien valssiohjelmiston otsakkeissa esiintyvät paikat.

Harmonikkasäveltäjät tuntuvat mielellään nimeävän kappaleensa paikan mukaan. Unto Jutila liikkuu kotiseudullaan Kalajoen varressa, mutta myös harmonikkafes-

\footnotetext{
${ }^{13}$ Espanja on taulukossa hieman harhaanjohtava maininta sikäli, että soitettu kappale on Pas d'Espagne. Se on kuitenkin pelimannien omassa luokittelussa sijoitettu valssien kategoriaan.
} 
tivaalipaikkakunta Ikaalisten rantatiellä. Ahvenainen on harmonikkoineen matkannut ainakin akselilla Åsele - Syväjärvi. Paikannimien lisäksi harmonikkavalssien otsakkeissa on paljon kaipuuta ja syksyä.

Virtain pelimanneissa oli 1980-90 -lukujen vaihteessa viitisentoista harmonikansoittajaa. Harmonikka, sitä soittaneet ja sille säveltäneet suomalaiset mestarit tulevatkin usein esiin pelimannien keskusteluissa.

Harmonikka on selvästikin onnistuttu artikuloimaan osaksi suomalaisuutta. Se saa edustaa suomalaisuutta monissa yhteyksissä. Maailman ja Pohjoismaiden mestaruuksia voittaneet harmonikansoittajat, Laihaset, Ahvenaiset ja Vesteriset ovat varmasti pönkittäneet suomalaisten itsetuntoa: tätä kautta harmonikasta on tullut suomalaisille tärkeä identiteetin lisärakennuspuu. Tämä on sikäli mielenkiintoista, että vielä 1920-luvun Etelä-Pohjanmaalla harmonikkaan saatettiin suhtautua jyrkän vihamielisesti "ryssän soittimena". Haastattelin Ylihärmässä 1920-luvun nuorisoseura-aktiiveja, jotka kertoivat, että eräissä iltamissa muuan talonisäntä oli käynyt käsiksi viisiriviseen. Vahva soittaja oli pitänyt puolensa, ja harmonikka repeytyi lähes kahteen osaan. Isäntä oli lähtenyt allapäin kotiinsa, ja haitari oli tullut jäädäkseen. ${ }^{14}$

Martin Stokes (1994) onkin sanonut, että muusikoilla on harakan asenne musiikillisten lainojen suhteen. Eri kulttuuripiireistä tulevien elementtien yhteen sovittaminen ei tuota heille vaikeuksia. Sen sijaan kylläkin äärikansalliset irlantilaiset saattavat piestä englantilaista instrumenttia, kitaraa, kantavan muusikon henkihieveriin.

Virtain pelimannit kunnioittavat eteviä harmonikansoittajia selvästikin melkoisesti. Esimerkiksi rovaniemeläistä Seppo Leinoa esitellään esiintymistilanteessa yhdeksi "tunnetuimmista säveltäjistämme". Suurelle yleisölle hän ei ole kovin tuttu, mutta esimerkiksi virtolaiset soittavat hänen Syksyn viesti -valssiaan paljon. Leinon yhteydessä muistetaan usein, samoin kuin Yrjö Saarnionkin yhteydessä, mainita yhteydet musiikkiopistoihin. ${ }^{15}$

Mestarien suomalaisuus tuodaan esille silloin, kun paikalla on ulkomainen vieras. Johtaja esittelee valssin Rantakoivun alla seuraavasti:

\footnotetext{
${ }^{14}$ Kaiken lisäksi saamme pikemminkin kiittää italialaisia harmonikkavirtuooseja kuin venäläisiä kromaattisen viisirivisen harmonikan juurruttamisesta Suomeen (vrt. Jalkanen 1989, 69-72).

${ }^{15}$ Yksi pelimanneista kertoo kuulleensa, että Saarnio matkusti "kuulema niinku eri paikkakunnilla ja teki kappaleen aina". Näin syntyi esimerkiksi Vesivehmaan jenkka. Saarniota mainostetaan usein "viulunsoitonprofessorina", vaikkei hän sitä varsinaisesti ollutkaan.
} 


\section{Esimerkki 1.}

1 A: Tämä on sitte (1.0) suomalainen (2.0) yks Suomen parhaista hanuristeista (1.0) Onni Laihanen on säveltäny tämän kappaleen.

Johtaja varmistaa myös muilta soittajilta, että Laihanen todellakin oli Suomen mestari harmonikan soitossa. Käännän kaiken ulkomaiselle vieraalle englanniksi. Seuraavaksi soitetaan Vili Vesterisen jenkka, ja jälleen meille, vieraalle ja marginaaliosallistujalle, rakennetaan kappaleen identiteetti sen tekijän kautta:

Esimerkki 2. $A=$ piirin johtaja. B: pelimanni, $C=H J$, D: ulkomainen vieras.

$\begin{array}{lll}1 & \text { A: } & \text { ( ) Vili Vesterinen. Kaikkein kuuluisin } \\ 2 & \text { B: vanhoista hanuristeista } \\ 3 & \text { A: niin vanhoista hanuristeista } \\ 4 & \text { C: This is by Vili Vesterinen who is the most } \\ & & \text { famous accordionist } \\ 5 & \text { D: (who) } \\ 6 & \text { C: Vili Vesterinen } \\ 7 & \text { A: hanurinsoittaja. Hyvä. YKS kaks kol nel } \\ & & ((\text { soittavat jenkan)) }\end{array}$

Valssia ei kuitenkaan esitellä varsinaisesti "kansallissuomalaisena", kuten on tangon laita. Seuraavassa ulkomaiselle vieraalle esitellään tango Tamara tanssii: "Sano sille että tämon semmonen kansallis semmonen kansallissuomalainen TANgo". Kun ryhmä soittaa Venströmmin polkan, johtaja toteaa itse englanniksi: "Finnish polka". Hän siis valitsee esittelyn kategoriaksi suomalaisuuden myös polkan kohdalla.

Mainittu "kansallissuomalainen tango" viittaa selvästikin nimellään toiseuteen, romaniuteen - Tamara tanssii. Tämä toisen ja oman jännitteinen yhteennivominen ja artikuloiminen onkin läsnä tangossa usein. Tangoissa esiintyvät paikat ovat myyttisiä ja eksoottisia ja eskapistisia: Firenze, Itämaa, Harakura, Lappi, Satumaa ja miksei saaristokin kohtaavat eksoottisen romanimaailman (Mustalaisprimas, Ruhtinaan viulu) - ja tyttö odottaa että "prinssi uljas nuori sadun ihmemaan" poimisi hänet mukaansa (Itämaista rakkautta).

Täysin vastakkainen mentaalinen kartta löytyy jenkkojen ja sottiisien otsakkeita analysoimalla. Kartalle voidaan sijoittaa Vesivehmas, Simpele, Kotikylä, Pohjasmäki (Virtain naapurikunnan Vilppulan kylä), Katariinan kamari - ja mikseipä lesken sylikin. Me seitsemänkymmenluvun eläneet saimme iskelmistä kyllästymiseen saakka kuulla Simpeleen ihmeellisistä siioista ja Parikkalan piioista. Jenkka ikään kuin avasi meille ikkunan mehevään, vanhan kansan markkinapaikkaan, josta syötävää ja piikoja ei pidä puuttuman.

Kuusikymmenluvulla muistan itse laulaneeni innolla kylänraitilla Vesiveh- 
maan jenkkaa, joka oli letkajenkan ohella hitti. Jäsenkategorioita jenkoissa ovat "maalaiset" ja "kyläläiset", joiden toiminta koostuu lähinnä jenkanjytkyttämisestä kesäillan hämyssä lauantai-iltaisin tanssilavoilla. Jenkoissa ollaan usein myös yöjalassa. Katariinan kamarissa valvotaan ihania kesäöitä. Ja vaikka lesken kamarissa nukkuukin monta tenavaa, lesken keittiö ja syli ovat miehelle mieluisia, lämpimiä ja kotoisia paikkoja. Kahvia keitellään ja ikkunasta katsoo kuu. Jenkan jytke osuu lattiaan tanakasti. Niin myös jenkkojen otsakkeet viittaavat reaalitodellisuuteen: sellaisen jalat maassa elävän suomalaisen miehen todellisuuteen, jossa onni otetaan irti arkielämästä.

Nainen saa edustaa tässä todellisuudessa jotakin ravitsevaa ja maanläheistä, piikaa ja leskeä, jota karu todellisuus on jo koulinut. Miehet ovat jenkoissakin toimivampia. Esimerkiksi Virtain pelimannien eniten soittama jenkka on Postipojan jenkka. Jo repertoaarin kappaleiden nimistä voidaan siis gender-näkökulmasta tehdä mielenkiintoista kategoria-analyysia. Naisten mukaan nimetyt kappaleet ovat usein ytimekkäästi, mutta moniselitteisesti paljaita: Katja, Marusha, Aila, Kyllikki, Paula. Miltä kuulostaisi iskelmän otsakkeena Veikko, Timo tai Aleksei? Tässä kohden voi halutessaan soveltaa karua vanhaa luokittelua: naiset ovat kaipauksen kohteita, miehet toimivia ja aktiivisia subjekteja. ${ }^{16}$ Miehet kategorisoituvat laulujen nimissä pikemminkin työnsä tai puuhansa kautta. Mies soutaa (Venemiehen valssi) ja rakentaa (ruoveteläinen Timpurin valssi). Mukana ohjelmistossa on myös foxtrot Kivikauden mies, jonka puuhat kyllä tiedetään. Poikkeuksena tästä luokittelusta mainittakoon kuitenkin Tampereen muijain pyykkipolkka.

Olen sijoittanut seuraaviin karttoihin (kartat 1 ja 2) kaikki paikkaviitteet, jotka esiintyvät ohjelmiston otsakkeissa, niin valsseissa kuin muissakin kappaleissa. Idean tähän sain lukiessani Steve Feldin kirjaa Sound and Sentiment (1990), jossa hän piirtää kartan kaluli-heimoon kuuluvan Hanen itkussa sa-yElab esiintyvistä lukuisista paikannimistä.

16 Pekka Jalkasen mukaan miehet tekevät tämäntyylisen tanssimusiikin kautta yksilöllisen ja kollektiivisen kosinnan (suullinen keskustelu). Uudemmassa populaarimusiikissa asiat lienevät hieman toisin, mutta uskoisin että kyseessä on kuitenkin mentaliteettimme melkoisen hitaasti muuttuva kerrostuma. 


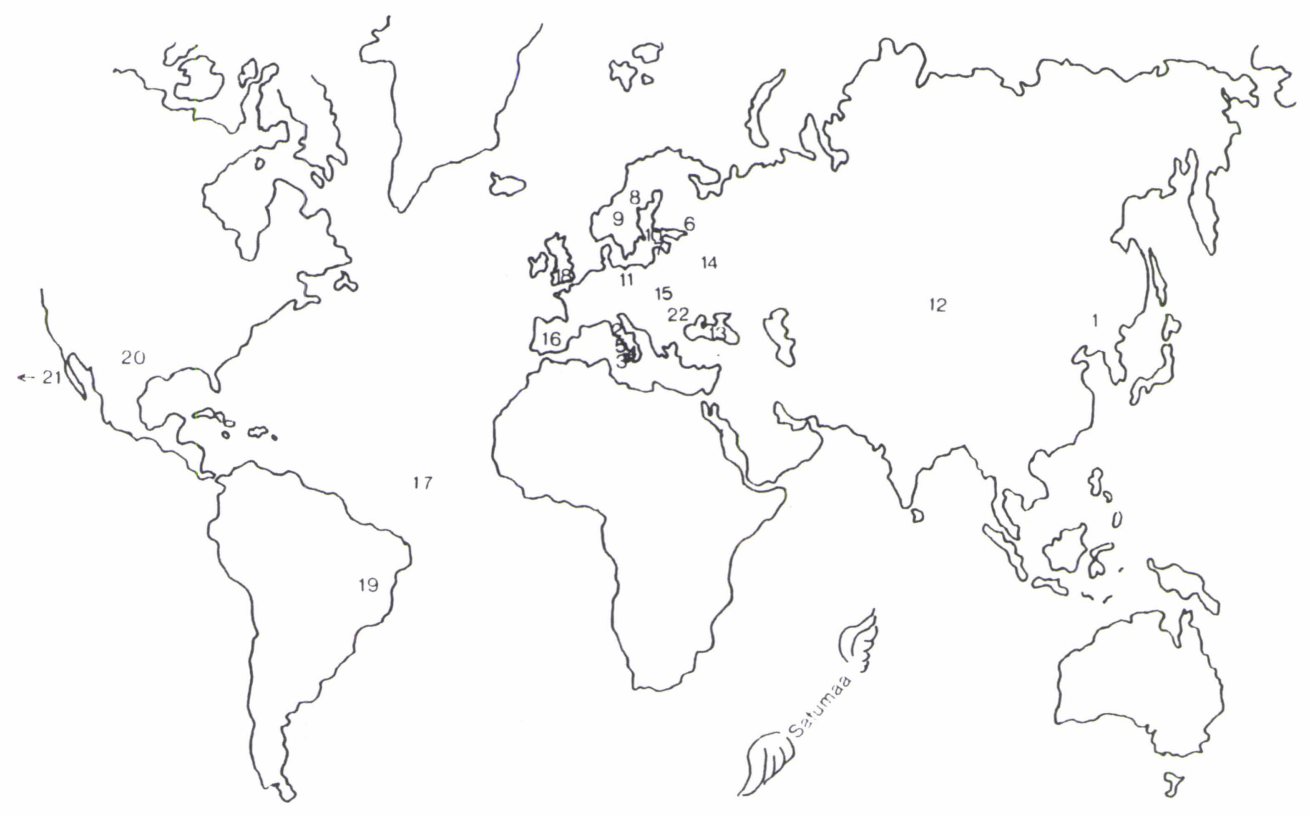

Kartta 1. Ohjelmiston otsakkeissa mainitut paikat, nuotteihin kirjatut alkuperäpaikat ja tiedossa olevat säveltäjien kotipaikat:

$\begin{array}{ll}1 & \text { Mantšuria } \\ 2 & \text { Firenze } \\ 3 & \text { Capri } \\ 4 & \text { Sorrento } \\ 5 & \text { Napoli } \\ 6 & \text { Valamo } \\ 7 & \text { Saarenmaa }\end{array}$

1 Mantšuria

3 Capri

4 Sorrento

5 Napoli

7 Saarenmaa
8 Åsele

9 Suomalaismetsät

10 Arholma

11 Saksa

12 Altai

13 Musta meri

14 Venäjä
15 Karpaatit

16 Espanja

17 "Tropiikki"

18 Englanti

19 Latinalainen Amerikka

20 "Länsi"

21 Havaiji

22 Romania 


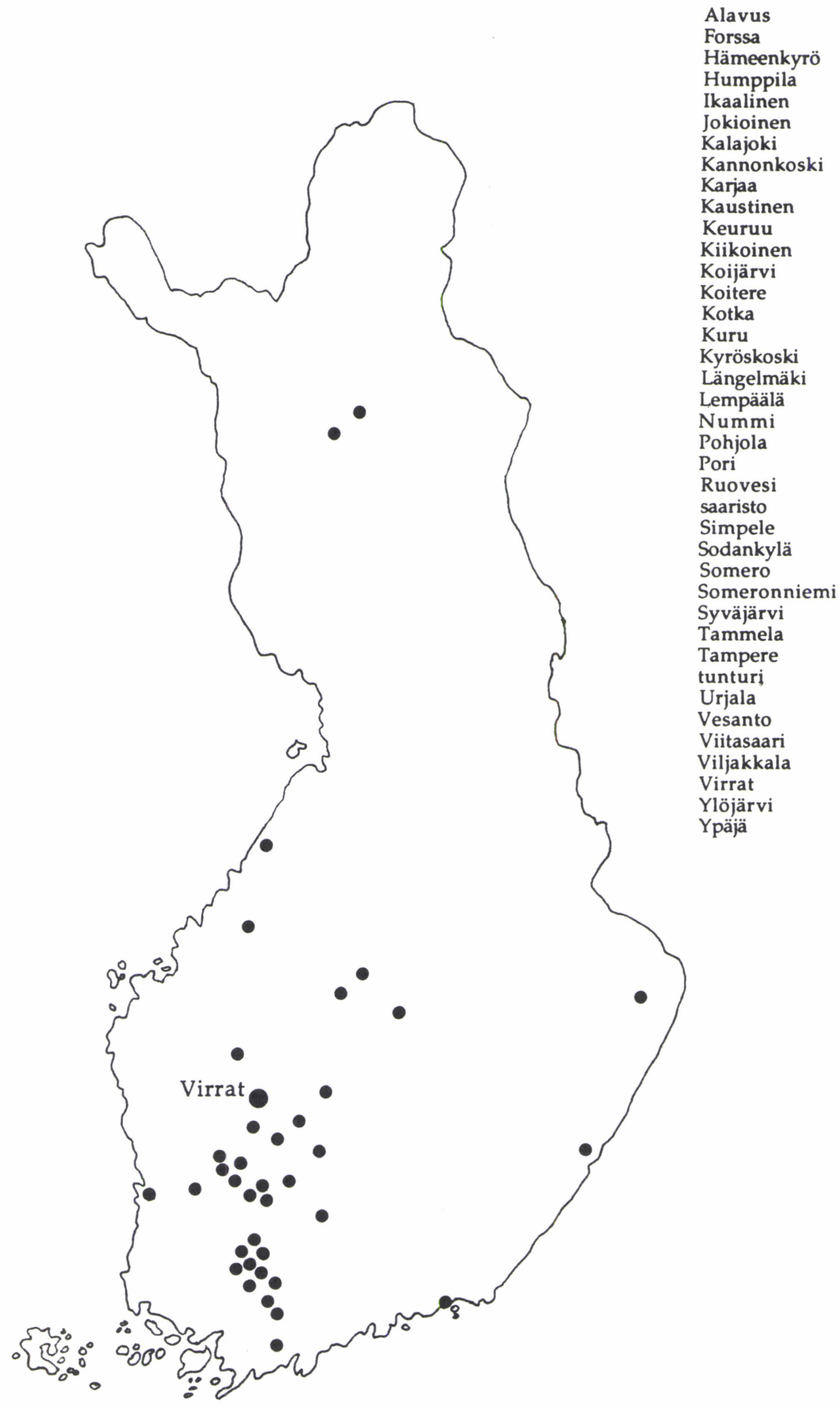

Kartta 2. Virtain pelimannien ohjelmiston otsakkeissa esiintyvät ja nuotteihin kirjatut kotimaiset paikat 


\section{Miten puheessa valsseista rakennetaan paikkaa}

Valssiohjelmiston eksoottisimpia paikkamielikuvia herättävät Venäjän suunnalta kulkeutuneet kappaleet kuten Mantšurian kukkuloilla, Muistoja Karpaateilta, Marusha ja suomalaissävellys Katjakin. Kahta ensiksi mainittua pelimannit eivät harjoitusten lomassa kommentoi mitenkään - ikäänkuin ne olisivat täysin suomalaistuneet. Sen sijaan Marushan rajatila venäläisyyden ja suomalaisuuden välissä tulee esiin.

Seuraavassa paikka identifioidaan tutkijalle. En kuullut kunnolla juuri soitetun Marusha-kappaleen nimeä:

Esimerkki 3. Y 9626; ETH 1685-1692. A= piirin johtaja, B ja D=pelimanneja, C=HJ.

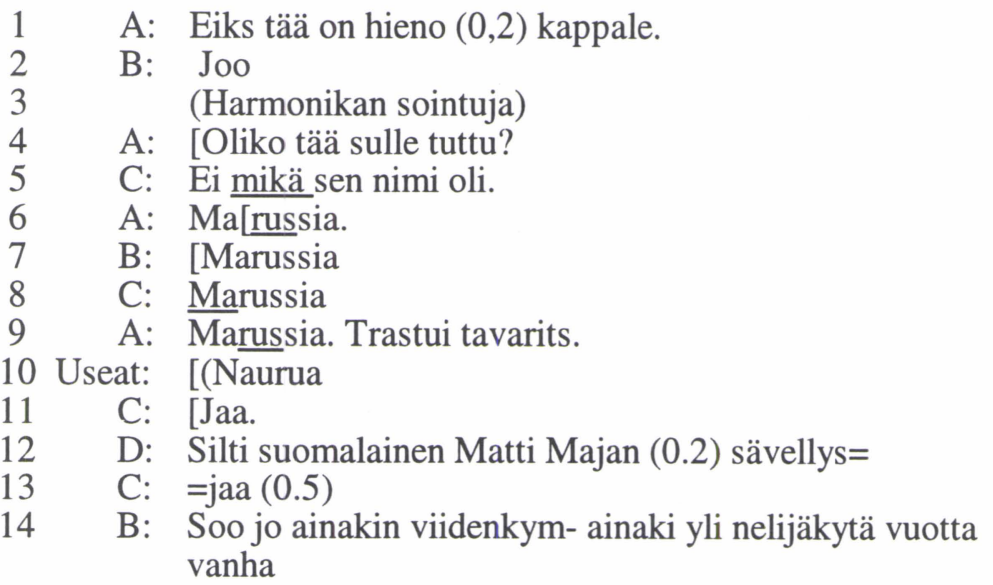

Piirin johtaja arvioi kappaletta, joka - vaikka rivillä 12 toisin kerrotaan - on alkuperältään venäläinen mustalaisromanssi. Hän kysyy minulta, tunnenko kappaleen. En sano tuntevani, ja kun kysyn sen nimeä, saan vastauksen heti johtajalta ja osittain päällekkäin toiseltakin pelimannilta. Toistan kappaleen nimen, en siis käytä mitään selkeää asian ymmärtämisen ilmaisua. Tällöin johtaja katsoo aiheelliseksi antaa vielä lisäselvitystä erikoiselle nimelle: rivillä 9 hän käyttää Suomessa yleisesti tunnettua "trastui tavarits" -fraasia ja sijoittaa näin kappaleen venäläis-kategoriaan.

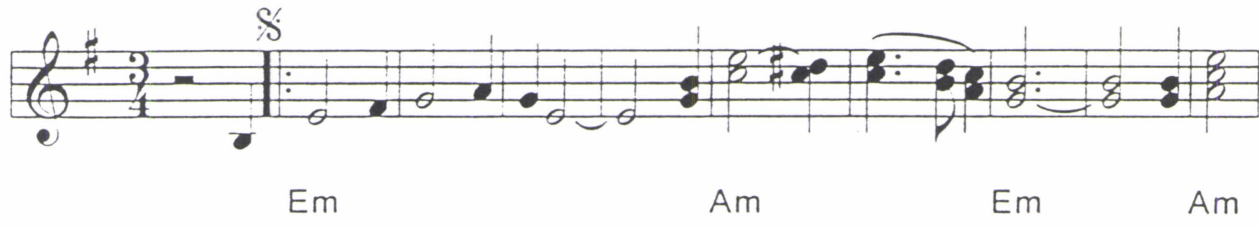

Nuottiesimerkki 1. Marusha. 
Seuraavat kommentit paljastavat, että fraasi yhtäältä informoi kappaleen etnisestä kategorisaatiosta. Toisaalta se ymmärretään huumorina - useiden pelimannien välitön reaktio on nauraminen. Samaan aikaan totean "jaa": selvitys riitti selittämään minulle tämän kummallisen kappaleen nimen. Näennäinen intersubjektiivinen yhteisymmärrys kappaleen sijoittumisesta venäläiskategoriaan ei kuitenkaan kestä kauan. Pelimanni D rakentaa kappaleelle uuden identiteetin dimension: se on "suomalainen" "Matti Majan" (Martti Jäppilän) sävellys. Pelimanni B vielä sijoittaa kappaleen aikaan, neljän-viidenkymmenen vuoden taakse. Myöhemmässä keskustelussa D vielä tarkentaa tämän 20-30 -luvulle, jolloin kappaleen kronotooppi, aika-paikka - käyttääkseni Bahtinin ilmaisua - tulee entistä tarkemmaksi.

Tämän tapaisella keskustelulla on merkitystä myös Virtain pelimannien identiteetin kannalta. Idästä tuleva eksoottinen - Marushan tapauksessa venäläisen mustalaisromanssin raskasmielisyys - konstruoidaan suomalaisen säveltäjän kynän kautta suodattuneeksi. Venäläinen toiseus tehdäänkin säveltäjän nimeämisellä osaksi suomalaista musiikkia, jota virtolainen pelimanniryhmä voi käyttää oman identiteettinsä rakennuspuuna.

Etnisyyskategorisointi aktualisoituu myös ohjelmiston ruotsalais-valssien kohdalla: Arholma ja Koster-valssi kategorisoidaan aina ruotsalaisiksi: Seuraavassa esimerkissä yhtye on valitsemassa esitysnumeroksi valssia omaan pelimannijuhlaansa ja sopivista valsseista on puutetta, kuten johtajan puheesta käy ilmi: "Sanokaa joku valssi, meillei ole valssia kertakaikkiaan, muuta ku sata". Arholma ja Koster-valssit ovat sopivia, koska ne menevät nuotteihin vilkaisematta.

Esimerkki 4. Y 9617; ETH 414-418 (YR: piirin johtaja).

1 Soittavat Koster-valssin.

2 YR: Tää on ruottalainen.

3 (Ehdotetaan Arholma-valssia.)

$4 \quad$ YR: Sekin on ruottalainen

Ruotsalaisiksi kategorisoidut valssit ovat musiikillisesti kovin erilaisia kuin venäläiskategoriaan kuuluvat mollivalssit. Duurikolmisointu-pohjainen "sjömansvals" tulee etsimättä mieleen.

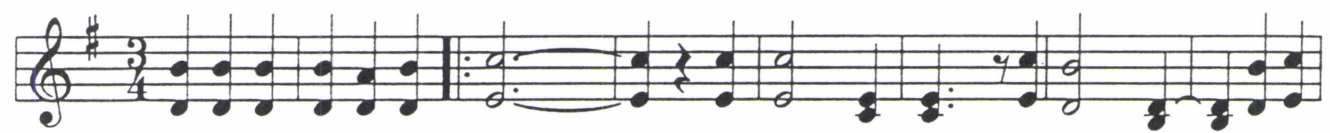

G7

C

G

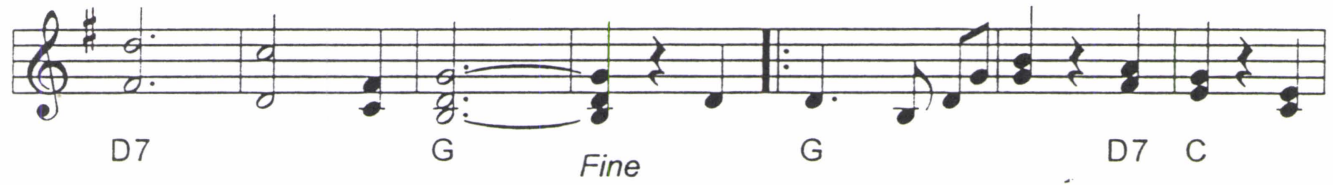

Nuottiesimerkki 2. Kostervalssi. 


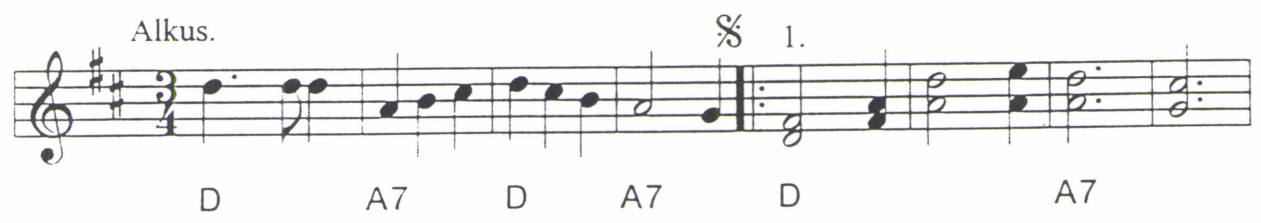

Nuottiesimerkki 3. Arholma-valssi.

Repertoaarin suomalaisista valsseista etenkin vesiaiheisissa on merimiesvalssielementtejä. Ajatellaanpa vaikka Pentti Viherluodon Aamu Airistolla -kappaletta. Virtolaisista duurivalsseista mainittakoon Erkki Alanteen Myötätuulessa. Myötätuulessa identifioidaan kuitenkin virtolaisuuden kautta ja näin sitä voidaan vakavasti harkita edustamaan paikkakuntaa näytön paikassa, pelimannien järjestämässä Hämeen kevätsoitossa.

Esimerkki 5. Y 9626; ETH 1826-1832. A: pelimannien johtaja; B: yhdistyksen taloudenhoitaja; C ja D: muita pelimanneja.

1 A: Onko teillä mitään sitä vastaan jos Urho ja minä ja Matti

2 valikoidaan ne yhteiskappaleet ja mää kirjotan ja lähetän ne

3 (1.0) eteenpäin (1.0) ja ne pitää olla aika lailla yksinkertasia

$4 \quad$ ( ) isot porukat soittaa. (2.0)

$5 \quad$ B: Mää jo äskön sanoin Yrjö että se Myötätuulessa olis yks

6 mahollisuus ku se on virtolaissyntysen säveltäjän ( ) kappale

$7 \quad$ C: $\quad$ Yksinkertanen kappale

8 D: mikä=

9 B: $=$ se Myötätuulessa, se Alanteen Erkin kappale

10 D: Joo

Toista iloista duurivalssia, Venemiehen valssia, havitellaan saman tapahtuman kaikkien, eri puolilta Hämettä saapuvien pelimanniryhmien yhteiskappaleeksi. Sitä siis voidaan harkita edustamaan, ellei paikallisuutta, niin alueellisuutta ainakin. Virtolaisuuteen kappaleen "vetisyys" liittyy: Virrathan on ylt'ympäriinsä järvien ympäröimä. 


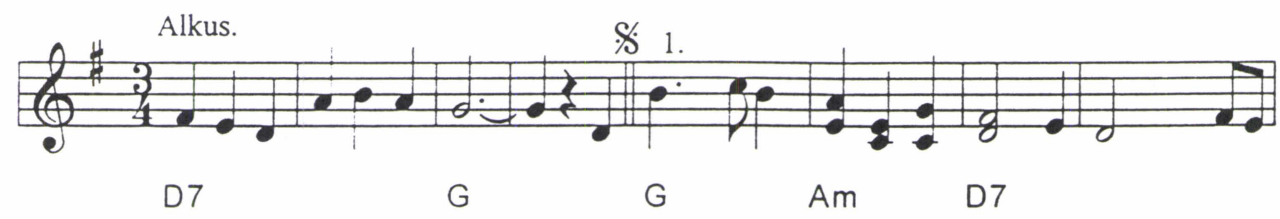

Nuottiesimerkki 4. Myötätuulessa.

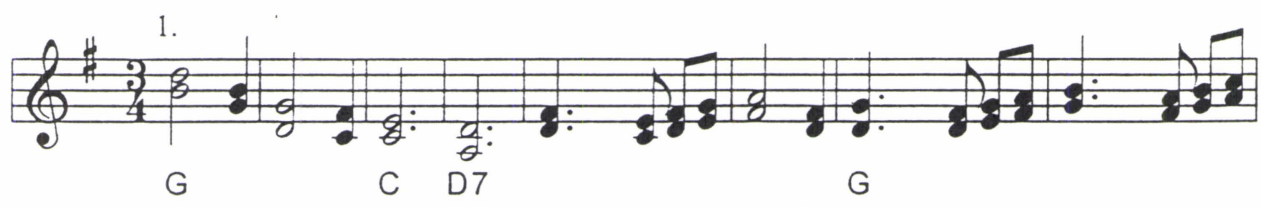

Nuottiesimerkki 5. Venemiehen valssi.

Jälleen tutkija, "rinsessa" (ks. Järviluoma 1991), on sopiva kohde, jolle johtaja voi kategorisoida kappaletta ajassa ja paikassa (rivi 1). Samalla sen käyttökelpoisuus yhteissoittokappaleena tulee muillekin legitimoitua:

Esimerkki 6. Y 9628; ETH 2154-2163

1 A: Onko:: (0.5) onko rinsessa kuullu tätä (0.5)

2 B: En oo (0.5) koskaan aikasemmin. (1.0)

3 A: Tää on $\underline{\text { iänikusen [vanha valssi (1.0) }}$

4 C: [(ote)taan uuvestaan

5 A: \$Mennään mennään \$ $(0.5)$ ja tota $(1.3)$ jotkut väittää että

6 se on täältäpäin kotosi-=jotkut väittää että se=on Pohjan-

7 maalta kotosi, jotkut väittää että se on tuota (0.5) Karijalasta

8 kotosi, ei: kukaan tiedä. (.) Mutta soutupaikasta,

9 soutupaikasta on kysymys.

10 B: Jaa. (1.3)

11 A: Ei näistä tierä. (2.0) On ollu puhetta että otetaan se

12 Hämeen (.) kevätsoiton yhteiskappaleeksi sen takia että (0.2) tää sopii

13 (sottiisien--) ( - - ) pirtee kappale

14 B: Joo::으

Johtaja ei siis pysty sijoittamaan kappaletta tarkkaan aikaan - se on "iänikusen vanha" - eikä myöskään paikkaan. Silti löysäkin yhteys Hämeeseen riittää. Kappaleen alkuseudusta on ristiriitaisia tietoja: "jotkut" väittävät kappaletta milloin täältäpäin, milloin Pohjanmaalta, milloin taas Karjalasta kotoisin olevaksi 
(rivit 6-8). Jälkimmäisten maakuntamainintojen valossa myös johtajan epämääräinen ilmaisu "täältäpäin" voidaan kategorisoida maakunnaksi. Kiinnostavaa onkin, että puhuja valitsee nimenomaan maakunnat paikantamisen välineiksi. Riveillä 11-12 tullaankin siihen, että "on ollut puhetta että otetaan se Hämeen kevätsoiton yhteiskappaleeksi". Puhe jo pohjustaa tätä lausumaa. ${ }^{17}$

Rivillä 11 johtaja myös mainitsee, ettei "näistä tiedä". "Näillä" hän ilmeisesti tarkoittaa kansansävelmiä. Tässä tapauksessa näyttää riittävän, että kolmesta mahdollisesta syntypaikasta "täältäpäin" on aivan yhtä mahdollinen kuin muutkin. Rivillä 8 hän kuittaa edelliset kommentit yhtä painavalla kommentilla "mutta"partikkelin avulla: "mutta soutupaikasta, soutupaikasta on kyse".

Näyttää siltä, että kun Virtain pelimannit valitsevat kappaleita, niin omia soittokappaleitaan kuin yhteissoittokappaleitakin järjestämäänsä Hämeen kevätsoittoon, jokaisen kappaleen valinta edellyttää perusteluja. Perustelut ovat tilannesidonnaisia, ja elementtien arvojärjestystä voidaan muuttaa tarpeen mukaan. Venemiehen valssi esimerkiksi tyydyttää muusikkoja esteettisesti, jolloin muut perustelut saattavat olla kaukaa haettuja. Kappale on heidän mielestään "pirtee" ja sopii sottiisien kaveriksi.

Kuulin pelimannien arviointia edellisen keskustelun jälkeen. Pelimannit soittivat valssin, ja yksi pelimanneista huutaa:

Esimerkki 7. Y 9628. A ja C=pelimanneja; B= pelimannien johtaja.

1 A: Tässon hyvä toinen ääni

2 B: Siinoon erittäin hyvä toinen ääni. Kulukee koko ajan.

3 C: Kulukee koko ajan (-)

Hämäläisyyttä ei tarvitse enää perustella. Johtajan tarvitsee vain vahvistaa jonkun pelimanneista toteama lausuma, jonka kolmas jäsen edelleen vahvistaa.

Ruovesi-Virrat -polkan valitseminen samaan makuntasoittoon yhteissoittokappaleeksi sen sijaan aiheuttaa päänvaivaa sen vuoksi, että se on musiikillisesti epätyydyttävä. Mutta koska se voidaan epäilyksettä sijoittaa tarkasti lähiseudulle, esteettiset kriteerit voidaan ohittaa:

Esimerkki 8. ETH 2734-2746

1 A: HE:.I: ((1.0, ihmiset lopettavat soittamisen )) Me nyt sitten

2

tämmösen (.) Ruovesi-Virrat polokan otimme sinne pelimannien kaikkien pelimannien hämäläisten pelimannien yhteiskappaleeksi sen takia että tää on vähä täältäpäin. (1.5)

17 Virtolaiset puhuvat mielellään paikkakunnastaan neljän maakunnan risteyksenä: Hämeen, Satakunnan, Etelä-Pohjanmaan ja Keski-Suomen. Nykyään se kuuluu Pirkanmaan talousalueeseen, mutta historiallisesti Ylä-Satakuntaan. Viimeksi mainittua kuuluvuutta ei aineistossani tule lainkaan esiin. 
täältäpäin kumminki ku se on Ruovesi-Virrat polkka. Se on luultavasti tolta (1.8) tolta tolta Tuuhoskylästä (.) kotosin ku siellon niitä Kangasniemiä ja (.) ne Kangasniemet on taas kai tuolta Kotalasta lähtösin sen takia kai se on [Ruovesi-Virrat

[joku soittelee polkka vaimeasti polkkaa harmonikalla ja niitten suku on lähtösi Kotalasta ()

B: Pelimannitalakoitten yhteiskappale (*viime vuonna*) (3.5)

A: Nii (2.0)

C: Tää on vähä erikoinen nii=

$\mathrm{A}:=\mathrm{TÄÄ}$ ON SEMMONEN ERIKOINEN polkka tää on ainakin semmonen hirvittävän pelimannimainen. Ei tää nyt * on niitä ny tehty parempiaki polkkia*. JA LÄHTEE MENNÄÄN HISSUN KISSUN ihan vaan jankkaamalla minen ainakaan OSAA tätä.

Johtaja kiinnittää rivillä yksi soittajiensa huomion. Seuraa uutisia: perusteluja sille, miksi yhteiskappaleeksi kevätsoittoon on valittu nimenomaan RuovesiVirrat -polkka, vaikka se onkin "erikoinen" (rivit 15-16). Puhuja käyttää muotoa "me --- otimme" (1-2) eli hän puhuu koko valintaryhmän puolesta. Tämä ryhmä ei kuitenkaan kokonaisuudessaan ollut valinnasta tietoinen. ${ }^{18}$ Ehkä siksi tarkat perustelut ovat tarpeen.

Johtaja ensinnäkin etsiskelee ja tarkentaa kappaleen soittajaryhmää ensin pelimanneista kaikiksi pelimanneiksi ja sen jälkeen hämäläisiksi pelimanneiksi (rivit 2-3). Jos kyseessä olisi vaikkapa vain kaikkien virtolaisten pelimannien yhteiskappale, asiaa saatettaisiin protestoida. Sen juurten ruotiminen osoittaa, että kappale on vääjäämättä hämäläinen ja syy sen valintaan onkin se, että "tää on vähä täl̈ltäpäin (1.5) täl̈ltäpäin kumminki". Aivan varmaksi hän ei lähtöpaikkaa rakenna: "vähä", "kumminki", "luultavasti Tuuhoskylästä" (rivit 4-6). Johtaja rakentaa kappaleelle oletetut juuret. Linkkinä on Kangasniemen suku, jonka juuret ovat virtolaisessa Kotalan kylässä, mutta jota asuu Tuuhoskylässä.

Tämä riittäisi jo selitykseksi: joku alkaa jo soitella polkkaa puheen alla (rivit 10-11). Eräs valitsijaryhmän jäsenistä kuitenkin lisää edelliseen, että kappale oli edellisen vuoden pelimannitalkoiden (eli pohjoishämäläisten pelimannien kokoontumisen) yhteiskappale. Pitkät hiljaisuudet johtajan "niin" ympärillä ovat hieman pahaenteisiä. Joku pelimanneista pukee mielipiteensä varovaisesti sanoiksi: "tää on semmonen erikoinen nii=", jonka johtaja kiirehtii toistamaan. Onhan kommenttia jo odotettukin. Hän korostaa sanaa ERIKOINEN, joka onkin kiertoilmaus asialle, joka tulee jatkossa hiljaisella äänellä: "Ei tää nyt *on niitä ny tehty parempiaki polkkia*". Tätä edeltää kuitenkin positiiviseksi huomioksi tarkoitettu "tää on ainakin semmonen hirvittävän pelimannimainen". Viimeinen adjektiivi on

\footnotetext{
${ }^{18}$ Juuri ennen käsillä olevaa keskustelua johtaja nimittäin kysyi yhdeltä valintaryhmään kuuluneista, oliko kyseisestä polkasta ollut puhetta puhelinkeskustelussa ja sai kieltävän vastauksen.
} 
todella moniselitteinen. Tässä se on tarkoitettu positiiviseksi. Johtaja rakentaa kappaleen luonteen mielenkiintoisen moniulotteiseksi, erikoisesta pelimannimaiseen ja ei-parhaaseen-mahdolliseen. Onko pelimannimaisuus sitten jotakin hellyttävää amatöörimäisyyttä, joka antaa kaikkien kukkien kukkia? Vieläkään johtaja ei myönnä, että polkka olisi huono tai kömpelö: on vain olemassa parempienkin polkkien kategoria, johon tämä kappale ei kuulu.

\section{Muistoja Perikylästä -valssin analyysi}

Seuraavassa analysoimani Muistoja Perikylästä -valssin on säveltänyt Virtain pelimannien jäsen, Matti Tulijoki. Tarkastelun vertailuaineistoksi olen valinnut pelimannien ohjelmistosta 25 mollivalssia (ks. liite-taulukko 2), joista myös sanon sanasen.

Yrittäkäämme alustavasti sijoittaa Muistoja Perikylästä suomalaisen populaarimusiikin tyylien ja lajien joukkoon. Yksi asia on varmaa: se kuulostaa ns. vanhalta tanssimusiikilta. Se ei kuulosta reippaalta "merimiesvalssilta" tai "jonkin-vetisen-paikan-valssilta". Se on mollissa ja sisältää vain pienen duuritaskun. Se kuulostaa suomalaiselta, harmonikkavoittoisesti instrumentoidulta mollivalssilta.

Analyysissani olen käyttänyt runkona musiikkitieteilijä Philip Taggin populaarimusiikin analyysin muistilistametodia. Sovellan myös toisen saman alan edustajan, Olle Edströmin iskelmäanalyysi-ideoita ja Pekka Jalkasen väitöskirjassaan kehittämiä analyysitapoja (Tagg 1993; Edström 1989; Jalkanen 1989; vrt. Suutari 1993).

Seuraavassa analysoin valssin soitinparametreja, muotoa ja harmonisia elementtejä.

\section{Soitinparametrit}

Eri esityksissä Virtain pelimannien kokoonpano vaihtelee. Muistoja Perikylästä -valssin versio, jota analysoin tässä, on äänitetty studiossa. Se poikkeaa harjoituksissa ja esityksissä kuulemistani versioista siinä, että mukana ovat sähköbasso ja rumpusetti. Sähköbassoa en ollut aikaisemmin pelimanneilla nähnyt ja rumpusetti pystytettiin yleensä vain esitysten loppupuolella tanssiosuuden ajaksi. Pelimanniorkesteri muistuttaa soittimistoltaan 1930-luvun Dallapé-tyyppisten tanssiorkesterien kokoonpanoa paitsi siinä mielessä, että harmonikkoja on lukuisia: 


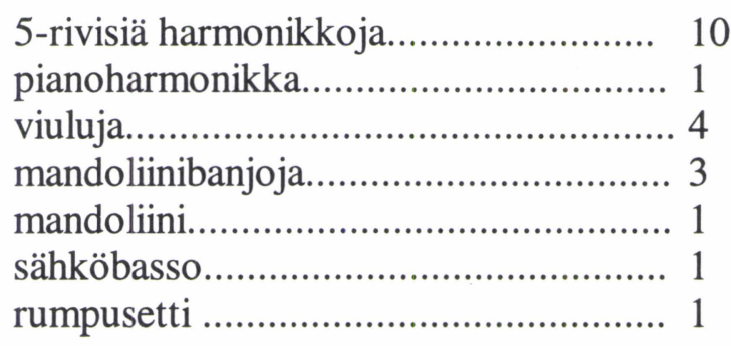

Taulukko 4. Muistoja Perikylästä -valssin instrumentaatio studioversiossa.

Virtain pelimannien aikaansaama äänimaisema on todellakin hyvin harmonikkavoittoinen. Viisirivinen harmonikka ei ole länsimaisen soittimiston hiljaisimpia soittimia, ja kymmenestä viiteentoista harmonikkaa saa aikaan paljon desibelejä - niitä en tosin koskaan mitannut.

Virtain pelimanneja perustettaessa, 1970-luvun alkupuolella, Virroilla toimi Martti Jytilän johtama hanuripartio. Kun pelimannit perustettiin, hanuripartion saundi artikuloitui pelimannien saundiin: mukaan tulivat myös viulut, mandoliinit ja banjot. Tällaisen kokoonpanon yhteiselo ei tietenkään ole voinut olla aivan kitkatonta, ja usein huomasinkin johtajan taiteilevan edistyneimpien hanuristien toiveitten ja muiden soittajien intressien välillä. Silti viulut, mandoliinit ja banjot kuuluivat yllättävän hyvin niin harjoituksissa, esityksissä kuin tässä studioäänityksessäkin. Mandoliinibanjojen voimakkaat näppäilyt ja tremolot (esimerkiksi silloin, kun harmonikat eivät soita soolo-osuuttaan), antavat kappaleelle omaa sävyään.

Pelimannien harmonikkasaundia voidaan pitää taggilaisittain museemina. Muistoja Perikylässä -valssin harmonikkasaundi on semioottisten mielleyhtymien kannalta tärkeää, eikä sitä voida vaihtaa ilman että kappaleen luonne enemmän tai vähemmän muuntuu (ks. myös tämän artikkelin kohdasta Hypoteettinen korvaamiskokeilu).

Artikkelin teeman, paikan, kannalta on mielenkiintoista, että instrumenttien sekoitus on melkoisen "kansainvälinen". Tähän asiaan en nyt syvenny, mainitsen vain, että tämä tarjoaisi aiheen omaan pieneen tutkielmaansa. ${ }^{19}$

\section{Muodon analyysia}

Pirkko Moisalan $(1990,132)$ mukaan etnomusikologisen musiikintutkimuksen perusasetelma on usein se, että

\footnotetext{
${ }^{19}$ Harmonikan juuret jäljitetään usein kiinalaisiin suu-urkuihin ja tietenkin myöhemmin mm. Italiaan; banjo Amerikkaan - puhumattakaan instrumentteihin käytettyjen materiaalien alkuperien moninaisuudesta. Viulunkaan kuusipuu ei yleensä ole Suomesta peräisin.
} 


\begin{abstract}
"tutkimuksen kohteena on kuulonvaraisesti siirtyvä ja muistinvaraisesti säilyvä musiikki, kun taas tutkija on enkulturoitunut ja koulutettu kirjalliseen musiikkikulttuuriin. Tavanomaisimmin tutkimus eteneekin siten, että äänitettyään musiikkiesityksen tutkija ensin nuotintaa musiikin ja tekee sen jälkeen nuotinnoksistaan musiikkianalyysin".
\end{abstract}

Tutkimani musiikki ei sovi kuin osittain yllä olevaan asetelmaan. Virtain pelimannien musiikki soitetaan nuoteista. Osa pelimanneista ei niitä tunne, joten heille musiikki on siirtynyt kuulonvaraisesti ja säilyy muistinvaraisesti. Monet soittavat ilman nuotteja, vaikka niitä osaavatkin lukea: ovathan jotkin kappaleet olleet ohjelmistossa vuosikymmeniä. Toisaalta: jotkut käyttävät nuotteja aina, olipa kappale miten tuttu tahansa. Johtajan jakama nuotti (nuottiliite 1) ei luonnollisestikaan anna kuin aavistuksen siitä, miten kappale soitetaan ja miltä se kuulostaa. Olen tehnyt analysoimastani valssista myös oman nuotinnokseni (nuottiliite 2).

Minkälainen sitten olisi tässä tapauksessa Pirkko Moisalan (mt.) peräänkuuluttama kulttuurisensitiivinen analyysimetodi? Tällaisessa analyysissa ponnahduslautana ovat tutkittavan musiikkitradition, musiikkikulttuurin tai musiikinlajin omat sisäiset painotukset. Silti ei pyritä luomaan täysin kulttuurin sisänäkemyksen kanssa identtistä kuvausta: lopputulos on tutkijan tulkinta (mt. 134).

Tässä artikkelissa käytän toisaalta tätä melkoisen perinteistä länsimaisetnomusikologista musiikkianalyysia, ${ }^{20}$ mutta pyrin samalla tekijäorientaatioon ymmärtämään "tekijän näkökulmaa" (vrt. Moisala mt. 135). Tässä asiassa on ollut huomattavasti eduksi se seikka, että olen itse osallistunut musiikin tekemiseen, soittanut tutkimani ryhmän mukana sen harjoituksissa ja esiintymisissä.

Kulttuurisensitiivisen musiikkianalyysimetodin yhtenä perusoletuksena on että "muusikot tietävät, minkälaista musiikin tulisi olla ja miten sitä pitäisi esittää". (emt.) Musiikki "elää" tietona musiikintekijän mielessä (emt.). Tässä kohden lähestymistapa muistuttaa huomattavasti etnometodologian perusajatusta: "kyllä kansa tietää". Kiinnostavaa on analysoida niitä metodeja, joita tutkittavat ihmiset itse käyttävät luodessaan sosiaalista järjestystä tai kuten tässä tapauksessa, soivaa musiikkia. Tällöin en analysoi pelkästään ns. "musiikkia" (vrt. Grenier 1990) vaan myös siihen liittyvää puhetta, käyttäytymistä ja musiikin tekemisen konteksteja.

Silmätäänpä lähemmin Perikylä-valssin muotoa. Miten siitä voisi puhua?

\footnotetext{
${ }^{20}$ Olen saanut musiikkianalyysikoulutukseni perustan lähinnä pitkäaikaisessa musiikkiopistoopiskelussani: se on perinteiselle, länsimaisen taidemusiikin teorialle perustuva koulutus. Etnomusikologian opinnot ovat muokanneet tätä perustaa tuntuvasti. Uskon kuitenkin, että ajan myötä tämä perinteinen termistö täytyy käydä perusteellisesti läpi: sen käyttökelpoisuus täytyy arvioida perusteita myöten. Esimerkiksi Erkki Pekkilä teki väitöskirjassaan (1988) tätä työtä. Generatiivisten kielioppien rakentamista kohtaan on kuitenkin esitetty kritiikkiä, mm. juuri sen vuoksi, etteivät kryptiset kaaviot tahdo avautua ulkopuolisille (vrt. Walser 1993). Mm. Risto Blomsterin tekemä selkeytetty sovellus Nicholas Ruwet'n metodista vaikuttaa kehittelyn arvoiselta idealta.
} 
Muoto voidaan esittää esimerkiksi seuraavina merkkeinä:

Taitteet: $\quad \mathrm{C} \quad$ :A: $: \mathrm{B}: \quad: \mathrm{C}: \mathrm{A}$

Iskualat: $\quad 8 \quad: 16:: 16:: 16: 16$

Termi "kehyssikermä" ei määritä Perikylän valssin muotoa riittävän tarkasti. Helppoa on nimetä "kolmitaitteisen sikermän" johdanto (8 ensimmäistä iskualaa), päätaite (A) ja sen kertaustaite lopussa (A). Mutta entä B- ja C-taitteet? Kumpi on välitaite, ja miten jäljelle jäävää taitetta kutsutaan?

Jos taas kertausmerkit otetaan pois, valssi voidaan nimetä jaksomuodoksi, joka koostuu parisikermistä. Tämä nimitys ei kuitenkaan kerro oikeastaan mitään oleellista kappaleesta.

Havainnoidessani ryhmän toimintaa ja myös omasta kokemuksestani populaarimusiikin soittajana tiedän, että taitteita ja niiden kertauksia voidaan tarpeen mukaan poistaa ja lisätä.

Perikylän valssin studioversion ovat sovittaneet piirin johtaja Yrjö Raja sekä Virroilla vaikuttava unkarilaissyntyinen musiikinopettaja Kàlman Horvath, joka on tehnyt kappaleeseen toisen äänen (ks. pelimannien oma nuotti, liite 1). Analysoimani esitys onkin monien ihmisten vuorovaikutuksen tulosta: sen tekemiseen on tarvittu pitkä sarja päätöksiä siitä, mikä on "hyvää" musiikkia (vrt. Frith 1996). Sovituksessa kappale on lyhentynyt, mutta säveltäjä antaa tälle hyväksyntänsä:

Esimerkki 9. ETH 3293-3299. A: johtaja; B: säveltäjä.

1 Pelimannit soittavat valssin Muistoja Perikylästä. Johtaja

2 huutelee kertausohjeita väliin

3 A: Mitä sanoo säveltäjä itse

$4 \quad$ B: $\operatorname{Kyllä~se~(~)~}$

$5 \quad$ A: Niin

6 B: Sopivan mittanen on nyt

Johtajakin on tyytyväinen kappaleeseen lyhyempänä versiona ja kertoo aiemmin johtamistaan Ikaalisten pelimanneista, jotka halusivat soittaa kappaleet hyvinkin pitkinä, viisikin säkeistöä kertauksineen.

Kertausohjeet Raja kääntää myös niiden ymmärrettäviksi, jotka eivät tunne musiikkiterminologiaa. Seuraavassa johtaja selittää merkkejä, joita käyttänyt kirjoittaessaan Muistoja Perikylästä nuotin puhtaaksi Hämeen kevätsoittoa varten: ${ }^{21}$

\footnotetext{
${ }^{21}$ Yhtenä kansalaisopiston pelimannipiirin tehtävänä johtaja kuitenkin näkee myös musiikinteorian alkeiden opettamisen. Aina sopivissa väleissä hän kertoileekin tällaisia perusasioita. Monille nämä asiat ovat kuitenkin tuttuja, esimerkiksi aiemmilta torvisoittokuntavuosilta.
} 
Esimerkki 10. KPL Y 9628, 402.

Kolomannen nuottirivin (1.0) kolomannen nuottirivin päässä on kissinpää. (2.0) Ja siitä kun mennään toisen kerran (1.5) siis ku mennään ensin läpitte alakusoitto, (sit) ykkönen kerrataan, kakkonen kerrataan ja kolmonen kerrataan (0.5) ja sieltä lähetään segnosta segnoon (0.5) eli ykköseen ja sitte ku päästään sen kolmannen nuattirivin päähän siellon kissinpää (.) nii se pomppaa sinne ihan loppuun ja siellon se fine mut siitoon jääny kiriottamati se fine.

Sovituksessa kappaleeseen on "kissinpäiden" lisäksi ilmestynyt toinen ääni. Johtaja värvää parhaiten nuotteja taitavat, "nuottikonneet", soittamaan näitä toisia ääniä:

Esimerkki 11. Y 9631.

NIITÄ TOISIA ÄÄNIÄ SAA RUVETA OTTAMAAN SIELTÄ. ÄS VEE (0.2) ÄS VEE UU (.) sieltä hyvänä nuottikonneena (3.5) Kalle ja Törmän Vesa ja (1.0) Ketäs niitä nyt on (1.0) ja meidän Toivommekin vois koukkia niitä toisia ääniä, hyvänä nuotti-ihimisenä. Tekis HYVÄN säväyksen.

Mainitut soittajat - instrumentteinaan harmonikka, viulu ja banjo - sekä muutamat muut harmonikansoittajat tekivätkin työtä käskettyä. Toinen ääni kuuluukin kohtuullisen voimakkaasti studioversiossakin (ks. nuottiliite 1; en liittänyt toista ääntä nuottiin 2).

Muistoja Perikylästä -valssin C-osaan luotiin harjoituksissa, esityksissä ja myös kasetilta kuultavassa studioversiossa instrumentaalivälikkeen tuntua: ensimmäisen kertauksen soittivat pelkät harmonikat (ja studiossa sähköbasso). C-taite muistuttaa rytmillisesti hyvin läheisesti sellaisten laulettujen valssien kuten M. Majan Tunturisatu ja Onni Laihasen Ota myös syömmeni C-osaa. Näissäkin tämä osa on instrumentaalivälisoitto.
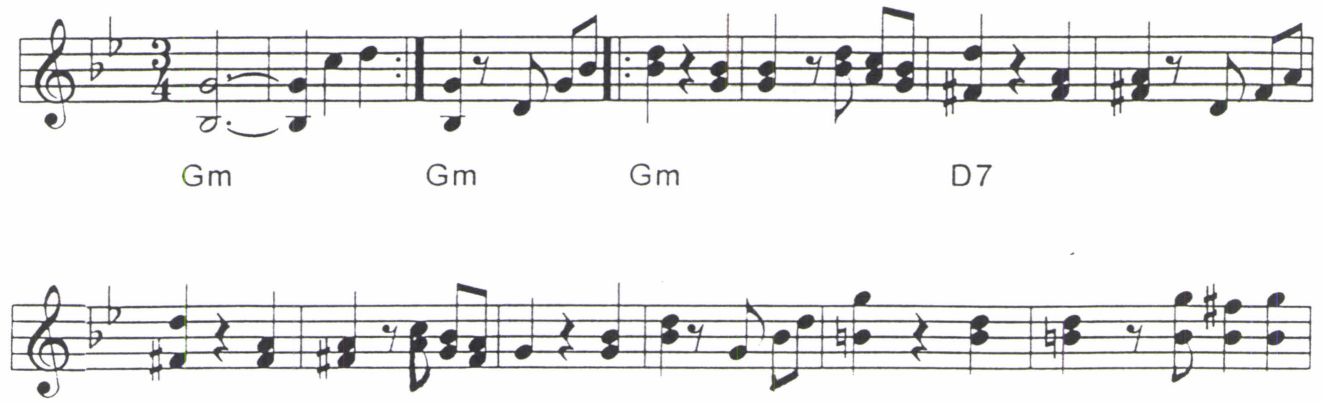

Nuottiesimerkki 6. Ota myös syömmeni. C-osasta. 
Niistä 25 mollivalssista, joita analysoin tarkimmin Ota myös syömmeni muistuttaakin - siinä muodossa kuin pelimannit sen soittavat - muotonsa puolesta melkoisesti Perikylän valssia:

\section{A B C $\left(A^{\prime}\right)$}

Veikko Ahvenaisen harmonikkavalssi Ilta Syväjärvellä on lähes samaa muotoa:

\section{$\mathrm{ABCA}$}

Vaikka Tunturisadun C-taite muistuttaakin rytmisesti likeisesti Perikylän Ctaitetta, nuotista päätellen Virtain pelimannit soittavat sen molemmin puolin kehyssikermän $\mathrm{ABA}$ :

\section{ABACABA}

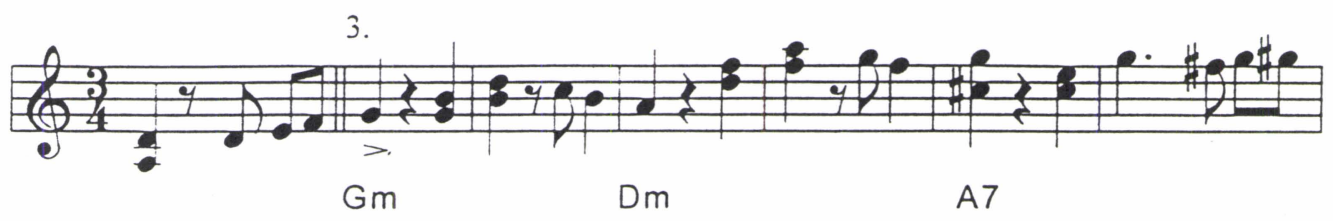

Nuottiesimerkki 7. Tunturisatu C-osasta.

Tunturisadun taitteet ovat lyhyempiä, ja sitä voidaan näin kertailla.

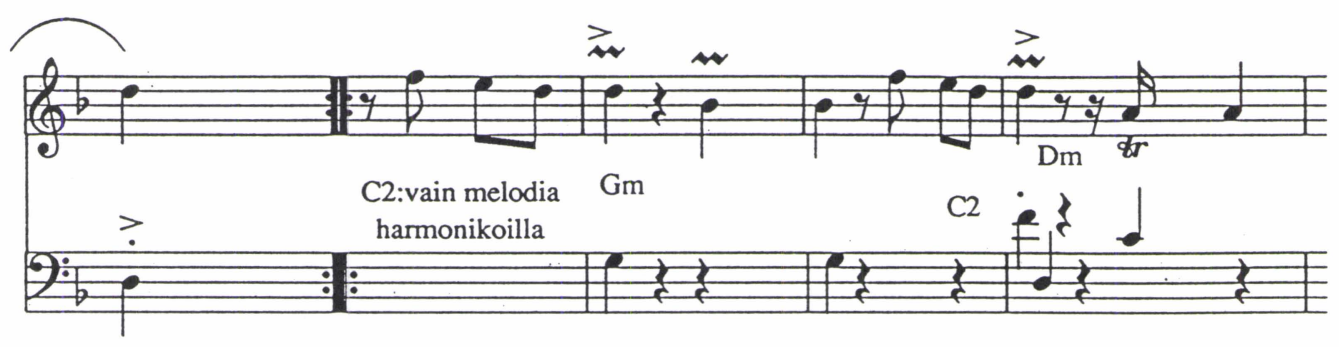

Nuottiesimerkki 8. Muistoja Perikylästä, C-osasta.

Kuten edellä totesin, C-osa vastaa Tunturisadun ja Ota myös syömmeni -tapaisten valssien instrumentaalivälikettä. Se alkaakin neljänneltä asteelta, "lepotehosta", mikä tuntuu kutsuvan toisenlaiseen toimintaan kuin perustehosta alkava Aosa tai dominanttilähtöinen B. C:n ominaislaadun selvittämisessä olisi ollut eduksi, jos olisin harrastanut enemmän parketeilla pyörimistä. Uskon nimittäin, 
että harrastunut valssintaitaja reagoi musiikin muutoksiin tanssityyliään muuttamalla. Erilaiset musiikilliset viestit kun saavat meissä aikaan erilaisia vartalon ja mielen liikkeitä (vrt. Middleton 1992). Sen verran "ruumiinmuistissani" on mielikuvia valssin tanssimisesta, että otaksun C:n sisältämien pikku taukojen muuttavan raajojemme liikkeitä keveämmiksi, hypähteleviksi.

Olle Edström onkin huomannut ruotsalaisia valsseja analysoidessaan, että noin $25 \%$ valsseista - nimenomaan vanhimmat hänen tutkimistaan 1910-1940 vuosien schlaagereista - sisälsivät Vers-Refreng muodon lisäksi lisäosan, jota kutsuttiin nimellä "efterdans", "dans" tai "trio". 1910-luvun alussa laulaja tai hupilaulaja tapasi hieman tanssahdella lavalla ja rallattaa tämän valssin osuuden, sillä sanoja siihen osioon ei kuulunut. Edström arvelee, että tämä osuus on muistumaa sekä Straussin valssien muodosta että menuettien tai ländlerien trioosuudesta. Ajan myötä nämä jälkitanssiosuudet kävivät ruotsalaisissa valsseissa yhä harvinaisemmiksi, kunnes jäivät käytöstä kokonaan. Viimeisessä valssissa, jossa tämä löytyy (Vind for våg) osuus on nimetty "fröjd-repris" -nimellä ilonpitoa ja tanssia varten siis.

Vaikka jälkitanssiosuus on kuihtunut ruotsalaisista valsseista, suomalaisissa valsseissa se näyttää olevan jotakuinkin voimissaan. Tapaamme sen selvästi sellaisissa uudemmissa harmonikka- ja kansanmusiikkivalsseissa kuten Seppo Leinon Syksyn viesti, Reino Kasittulan Leppäs-järven valssi - miksei myös Yrjö Rajan Mietteitä, vaikka se onkin kaksiosainen. Vili Vesterinen viimeinen levytetty sävellys (1953) Soittajan kaipuu ${ }^{22}$ sisältää ilmiselvästi trio-tyyppisen, kahdeksasosakulkuun perustuvan jälkitanssin, samantapaisen kuin vanhempi Sjöblomin Muistoja Pispalasta. Ulkomaisista valsseista jälkitanssiosuus on niin vanhemmassa ruotsalaisessa Koster-valssissa kuin slaavilaisessa Mantšurian kukkuloillakin. Vertailuaineistossa "jälkitanssittomat" valssit muodostavat itse asiassa vähemmistön (2/5). Näistä osa on selvästi tehty evergreen-kaavaan Verse-Refrain, esimerkiksi Malmsténin Särkynyt onni tai Kaunis valhe. Perikylän valssissa tapaamme trio- tai jälkitanssiosan selvästi. Pelkillä harmonikoilla soitettua C-osa hallitsee Aja B-osia huomattavasti rytmisempi aihe:

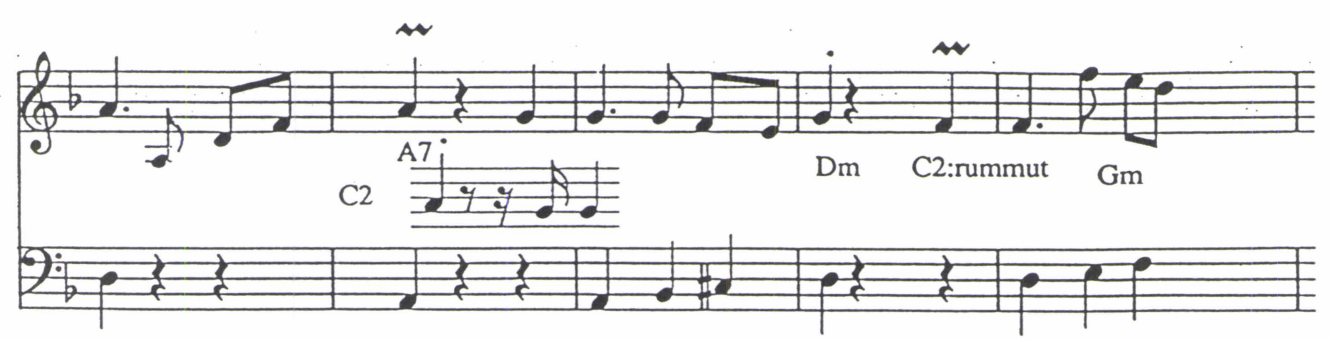

Nuottiesimerkki 9. Muistoja Perikylästä, C-osasta.

${ }^{22}$ Soittajan kaipuu ei kuulunut vertailuaineiston ydinjoukkoon. 
C:n säkeitten lukumäärästä voi olla useita mielipiteitä. Jos sitä halutaan pitää samanlaisena nelisäkeisenä muotona kuin edellisiäkin, sen säkeet näyttävät seuraavilta: a a' a b. a-säkeet kuitenkin jakautuvat säännöllisesti kahteen, usein pienen tauon erottamaan aiheeseen. Myös b-säe perustuu a:n aiheen muunnokseen.

Tutkiskellaanpa seuraavaksi lähemmin valssin A-lauseketta:
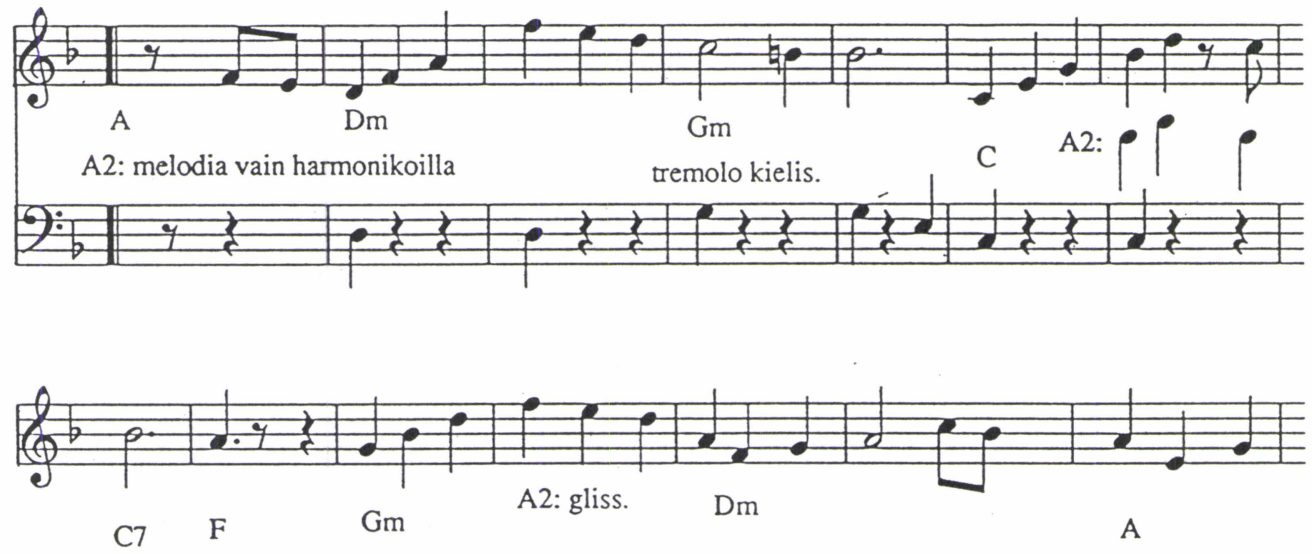

Nuottiesimerkki 10. Perikylän valssi, A-osasta.

A-osa on 16 iskualan mittainen nelisäkeinen parilauseke, jonka neljästä säkeestä kolme ensimmäistä on selvästi saman aiheen sekventiaalisia muunnoksia, ja neljännenkin aihelmat siitä muistuttavat: aa'a' b.

Ensimmäisessä säkeessä aihe alkaa perussävellajin murtosointu-kuviolla. Kuvion runkosävelet ovat desimin etäisyydellä toisistaan eli melodia päätyy yläterssiin, josta se tulee alaspäin asteittain. Lopussa melodia on hyvin romanttinen: siinä peräti kaksi kromaattista ääntä johdattaa appogiaturana huipputehon terssiin. Toisessa säkeessä aihe kertautuu sekä melodisesti että rytmisesti muuntuneena, sävelaskelta alemmalle sijoittuneena sekvenssinä. Samalla poiketaan tämän säkeen ajaksi rinnakkaissävellaji F-duuriin. Desimin sijasta aihe ulottuu nyt noonin alalle, ja nooni-sävel d:ssä onkin appogiaturan tuntua. Iskut osuvat kahdesti huipputehon septimille. Kolmas säe alkaa edellisten tapaan murtosointukululla, jonka ulottuvuus nyt on septimi. Tällä kertaa sekvenssi sijoittuu kvartin etäisyydelle ensimmäisestä. Säkeen lopetuksen melodia ei enää perustukaan yksinomaan alaspäiseen asteikkoon, vaan se on liikkuvampi ja kadenssoivampi se viihtyy huipputeholla, a-sävelessä, johon se alunperin laskeutuu kvarttia ylempää. Tästä päästäänkin helposti viimeiseen säkeeseen, joka alkaa dominanttisoinnulle perustuvalla portaittaisella murtosointuaihelmasekvenssillä ja päätyy perussäveleen ja peruskolmisointuun. 

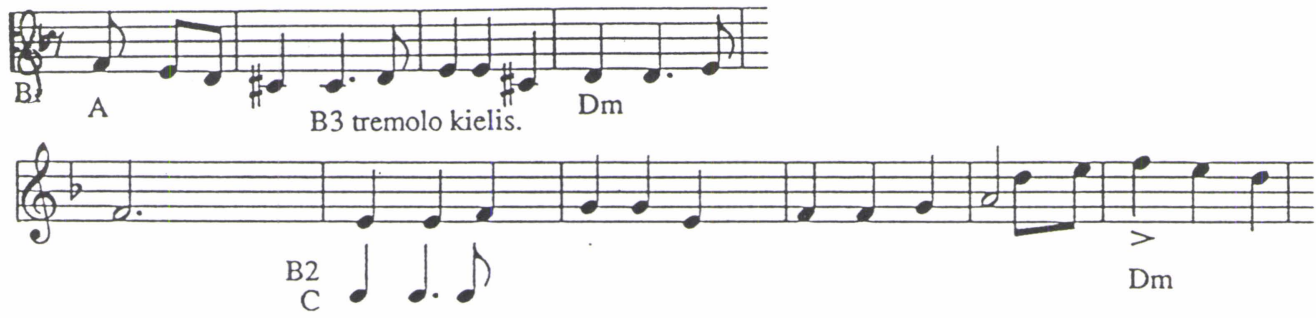

Nuottiesimerkki 11. Muistoja Perikylästä, B-osasta.

B-osa on A:n tapaan nelisäkeinen parilauseke: aa'bc. Ensimmäinen säe alkaa Aduurissa eli dominanttitehossa. Portaittain ylöspäin etenevä aihe sekvensoituu seuraavassa säkeessä rinnakkaissävellajiin, F-duuriin. Vain rytmi muuntuu aavistuksen verran: loppumuunteinen kolmisävel muuttuu tavalliseksi kolmisäveleksi. Ambitus on A-osan alkuun verrattuna suppea, kvartin laajuinen. B:n neljästä säkeestä kolme rakentuu selkeästi ylöspäiselle aiheelle (a, a' ja c). Kun a ja sen sekvenssi a' kiipeävät portaittain ylöspäin, niin b vuorostaan laskeutuu korkeuksista alas asteittaisina kolmisävelinä - aihelman piilomotiivi on seksti. Säe b päättyy lepotehosta vauhtia ottavaan alaspäiseen aihelmaan. Tätä laskeutuvaa säettä täydentää ylöspäiselle kolmisävelkululle perustuva jälkisäe, joka päättää B-osan.

\section{Intervallit, harmonia ja rytmi}

Muistoja Perikylästä -valssi muistuttaa monin tavoin venäläisiä "kaihoisia valssiromansseja" (Jalkanen 1989, 238), joiden kukoistuskauden alku sijoittuu 1800luvun lopulle. Toisaalta Suomeen vuosisadan loppupuolella levinneistä sävelmistä on kuultavissa monia valkovenäläisen ja ukrainalaisen kansanlaulun arkaaisia piirteitä: mm. modaalisia kulkuja ja kvintti- ja kvarttirakenteisia motiiveja. Suomessa tunnetuissa venäläisissä sävelmissä vallitsee kuitenkin yleensä tonaalinen melodinen ajattelu: harmonia, kitaran, pianon ja harmonikan säestyssoinnut. Tämän vuoksi kadensseille rakentuvat ambitukseltaan laajat murtosointukulut olivat tyypillisiä. Perikylän valssin A-osassa tapaamme lähes täysin laajoille murtosointumotiiveille perustuvan melodian, jota täydentää romanttinen kromaattinen pidätyskulku. Kappaleen ambitus on kvardesimi.

Venäläisen valssiromanssin motiivirakennetta dominoi kuitenkin seksti, erityisesti pieni seksti. Syyttä ei Boris Asafjev pitänyt 1800-luvun loppua sekstin aikakautena. (Asafjev i.v., 47; op.cit. Jalkanen 1989, 240.) Muistoja Perikylästä -valssissakin seksti esiintyy - esimerkiksi heti A-taitteen ensimmäisen ja toisen täyden tahdin rajalla. Se on myös B-taitteen kolmannen säkeen ja C-taitteessa useammassa säkeessä piilevänä motiivirunkona. 
Seksti ei suinkaan ole valssin useimmin esiintyvä intervalli (intervalleista $2 \%$ pieniä, ylöspäisiä sekunteja ja suuria ei ollenkaan) (ks. liitetaulukko 3). Melodia kulkee paljolti pieninä (24\%) ja suurina sekunteina (29\%) sekä pysyy paikallaan (14 \% priimejä). Murtosointumotiivien yleisyydestä johtuen sekä ylös- että alaspäisiä pieniä terssejä (10\%) ja kvartteja (noin $7 \%$ ) esiintyy kohtalaisesti. Kvinttejäkin, ylöspäisiä, kappaleessa on neljä (3\%) ja ne sijoittuvat melodiassa painottuviin kohtiin (esim. B-taitteen kolmannen säkeen keskelle). Kvintti esiintyy myös piilomotiivina. Varhaisessa venäläisessä romanssissa yleiset kvarttija kvinttimotiivit sekä murtosointukulut assosioituvat kansanmusiikkiin (esim. Jalkanen mt. 240). Murtosointumotiivit olivat toisaalta tyypillisiä myös saksalaisessa "pseudokansanlaulussa", wieniläisklassismissa ja schlaageriperinteessä (mt. 277-279). Perikylän valssi siis sekoittaa näitä piirteitä myöhäisemmän "sekstiintonaation" motiiveihin.

Tarkastelemani valssin harmonia perustuu I, IV ja V -soinnuille. Se sisältää kuitenkin poikkeamia rinnakkaisduuriin eli se ei kuulu harmonisesti aivan kaikista yksinkertaisimpiin valsseihin. Esimerkiksi venäläisten valssiromanssien harmonia on usein vielä pelkistetympää (Jalkanen mt. 242).

$\mathrm{d}$ :

1. jakso (A)

$\begin{array}{llllllll}\text { I } & \text { IV / } & \text { VI } & \text { III / IV } & \text { I } & \text { V } & \text { I } \\ \text { Dm } & \text { Gm } & \text { C } & \text { F } & \text { Gm } & \text { Dm } & \text { A } & \text { Dm }\end{array}$

2. jakso (B)

$\begin{array}{lllllllll}\mathrm{V} & \mathrm{I} / & \mathrm{VI} & \mathrm{III} & / \mathrm{I} & \mathrm{IV} & \mathrm{I} & \mathrm{V} & \mathrm{I}\end{array}$

A $\quad D m \quad C \quad F \quad D m \quad G m \quad D m \quad A \quad D m$

3. jakso (C)

$\begin{array}{llllllll}\text { IV } & \text { I } & \text { V } & \text { I } & \text { IV } & \text { I } & \text { V } & \text { I } \\ \text { Gm } & \text { Dm } & \text { A } & \text { Dm } & \text { Gm } & \text { Dm } & \text { A } & \text { Dm }\end{array}$

Kaikissa taitteissa on sama, autenttinen kadenssi: I-V-I. Tämän sointupohjan päälle on mahdollista rakentaa tiettyjä kappaleelle ominaisia tehokeinoja. Esimerkiksi ensimmäisen taitteen kolmannen säkeen "arkaainen" kvartti saa sävynsä, kun g-mollisoinnusta siirrytään d-mollisointuun eikä huipputeholle. B-taitteessa taas kolmannen säkeen kvintin jälkimmäinen sävel e paljastuukin romanttiseksi sekstipidätykseksi suhteessa perustana olevaan g-mollikolmisointuun.

Olen käyttänyt analyysissani myös pelkistettyä versiota ruotsalainen musiikkitieteilijä Olle Edströmin (1989) kehittämästä määrällisestä menetelmästä, jonka avulla voidaan tarkastella suurempienkin iskelmäaineistojen harmoniaa. Hän laski iskelmien sointujen lukumäärät, analysoi sointujen kompleksisuuden ja vaihtumistiheyden. Tätä menetelmää on käyttänyt myös Pekka Suutari ruotsinsuomalaisen tanssibändin tangomateriaalin analyysiin (1994).

Tarkastelin esimerkiksi valssien harmonista kompleksisuutta. Edströmin tarkastelussa kappale sai arvon 0, jos se sisälsi ainoastaan pääkolmisointuja ja vastaavia. Välidominantteja sisältävät saivat arvon 1 (01) ja vähennetyn septi- 
misoinnun tai muunnesoinnun sisältävät arvon 2 (02) jne. Tästä ei kannata rakentaa taulukkoa: mollivalssit saisivat lähes yksinomaan arvoja 0 ja 1 . Poikkeuksiakin on. Harmonikkavalsseista Unto Jutilan Kalajoki-valssi, Arvo Koskimaan iskelmä Keinumorsian ja ehkä myös Konsta Jylhän Parhaalle ystävälle voitaisiin sijoittaa ryhmään 2 . Yllättävää kyllä, myös Toivo Kärjen valssit ovat soinnutukseltaan yksinkertaisia, toisin kuin hänen tangonsa. Mollivalssit eivät siis ole harmonisesti kovin monimutkaisia, eikä Muistoja Perikylästä -valssi ole tästä säännöstä poikkeus.

Mollivalsseista "kaustislaisissa" kappaleissa (joista toinen on kaustislaiseen tyyliin sävelletty Kaustisen juhlavalssi) on eniten sointuja/16 iskualaa eli 6,7. Myös sointuvaihdoksia tapahtuu muihin ryhmiin verrattuna usein, yli kuusi kertaa/16 iskualaa. Englantilaisen Archibald Joycen Syysunelmia sisältää seuraavaksi eniten sointuja, 5,7 ja siinä sointuja vaihdetaan hieman tiuhempaan kuin venäläisessä Mantšhurian kukkuloilla valssissa. Syysunelmasta on sanottu, että se on venäläisempi kuin venäläiset romanssit itse (Jalkanen mt. 243), mikä pitäneekin paikkansa. ${ }^{23}$ Ryhmiä ei suinkaan kannata vertailla sokeasti toisiinsa, sillä ne ovat eri kokoisia. Esimerkiksi englantilaisia valsseja on aineistossa vain yksi.

$\begin{array}{cccccccc}\text { Ven } & \text { Engl } & \text { Virt } & \text { Kaus } & \text { Ukm } & \text { Isk } & \text { Harm } & \text { Perikylä } \\ 5 & 5,7 & 3,7 & 6,7 & 4,3 & 4,4 & 3,9 & 4,3\end{array}$

Taulukko 6. Virtain pelimannien ohjelmistosta valitun 25 mollivalssinuotin sointujen keskimääräinen lukumäärä/16 iskualaa.

Muistoja Perikylästä -valssissa on keskimäärin 4,3 sointua/16 iskualaa, mikä osuu täsmälleen samaan lukuun "Uuden kansanmusiikin" luvun kanssa - sattumaa, tai sitten ei. Virtolaiset muut valssithan kuuluisivat tähän kategoriaan myös, ellen olisi poiminut niitä erilliseksi ryhmäksi. Virtolaisissa valsseissa on toinenkin Perikylän valssin säveltäjän, Matti Tulijoen, sävellys Ristiniemen valssi. Perikylän valssissa soinnut vaihtuvat hieman verkkaisemmin kuin Ristiniemen valssissa. Perikylän valssin osioissa sointuvaihdoksia tapahtuu 7 (A), 8 (B) ja 7 (C) kertaa, kun taas Ristiniemen valssissa 3/4 osioista sisältää yli 9 sointuvaihdosta. Otoksen harmonikkavalssien harmonia on ehkä yllättävänkin niukka. Jutilan, Ahvenaisen, Laihasen ja Leinon tuotoksissa sointuja on vähemmän kuin "iskelmävalsseissa".

\section{Hypoteettisia korvaamiskokeiluja}

Yksi Philip Taggin museemianalyysin metodeista on hypoteettinen korvaaminen (hypothetical substitution). Tagg suosittelee teorian testaamista hypoteettisen

\footnotetext{
${ }^{23}$ Molemmat viimeksi mainitut valssit levisivät Suomeen jo tsaarinaikana torvisoittokuntalaitoksen välityksellä, joka olikin valssiromanssin tehokkain levittäjä tuolloin (mt.).
} 
korvaamisen avulla, jos tuntuu siltä, että tietty museemi tai museemiryhmä selvästi luo tiettyjä konnotaatioita analysoituun musiikkiin. Tällöin se musiikin osanen, jonka arvelen olevan semioottisesti merkityksellinen mielleyhtymien luomisessa, korvataan jollakin muulla.

Ossi Runnen 1967 ohjaamassa Konsta Jylhästä kertovassa TV-ohjelmassa tehtiin hieman samantyyppinen hypoteettinen substituutio. Siinä Konstan parempaa valssia soittivat vuoroin purppuripelimannit, vuoroin taas Suomen tuon ajan parhaat jazzmuusikot ja välillä 1700-luvun tyyliin pukeutuneet hovimuusikot wieniläisklassiseen tyyliin. Tässä sanoma oli selvä: Konsta oli koko Suomen Konsta, jonka musiikki artikuloitui pienin muutoksin mitä erilaisimpiin musiikillisiin diskursseihin.

Tein muutamia kokeiluja, siis taggilaisittain hypoteettisia korvaamisia, Perikylän valssin suhteen. Kun soitin tämän mollivalssin duurissa, se sai aivan toisenlaisen luonteen ja kuulosti merimiesvalssilta. Varsinkin C-jakso kuulosti duurissa hyvin rattoisalta, kun taas mollissa siinä on hitunen kohtalokasta, intohimoista parinpyöritystä. A-jakso perustuu kolmisointukuluille, joten merimiesvalssiassosiaatiot tulevat duurissa esiin. ${ }^{24}$

Muistoja Perikylässä -valssin mollisävellaji on siis semioottisten mielleyhtymien kannalta tärkeää, eikä sitä voida vaihtaa duuriksi ilman että kappaleen luonne muuttuu täysin.

Virtain pelimannit soittavat Perikylä-valssin tempossa MMI $=162$. Tempo on suhteellisen nopea ja kevyt, joten sitä ei voi huomattavasti nopeuttaa tai tanssiminen käy mahdottomasti. Hieman nopeutettuna kappaleen luonne kuitenkin muuttuu: se tulee keveämmäksi ja iloisemmaksi. Hidastin tempoon MM 100:n tasolle, jolloin vaikutelma on alkuperäistä laahaavampi ja melankolisempi. Tällöin C-taitteen hypähtelevä melodia tuntuu erityisen piristävältä. Tempolla siis on mielleyhtymiin selvästi vaikutusta.

Kokeilin syntetisaattorin ${ }^{25}$ avustuksella muuttaa Perikylän valssia tangoksi. Testasin myös valmiita rytmejä Vienna Waltz ja German Waltz. Tangoksi muuttaminen kävi suhteellisen vaivattomasti. Perikylän valssin melodiakulku sopisi lähes saumatta myös "suomalaisen tangon" melodiakuluksi. Kumpikin valssirytmi sopi säestykseksi, viimeksi mainittu kuitenkin ensimmäistä, hienostelevaa tyyliä paremmin. Koneeseen on laitettu joka kahdeksan tahdin jälkeen kadenssoivia rytmejä, jotka osuivat myös Perikylän valssissa kohdalleen: sen rakennehan muotoutuu 16-tahtisista taitteista.

Sitten vaihdoin harmonikka- tai pianosaundin klavikordin ääneksi ja säestystavan Haydnin sonatiineista tutuksi soinnutukseksi. Nyt säestys, soittimen saundi ja melodia olivat ristiriidassa keskenään. Haydn-keitos vaatisi melodiaan muutoksia: nyt se on liian romanttinen.

\footnotetext{
${ }^{24}$ Lyhyen 8 tahdin A-jakson duuriosuuden soinnut C-F täytyi duurissa muuttaa soinnuiksi A-D.

${ }^{25}$ Technics KN550.
} 
Sen sijaan venäläisen valssiromanssin Perikylän valssin tapaisesta mollivalssista varmasti saisin pienin retusoinnein.

\section{Loppusanat}

Löytyikö pelimannimusiikista "traktorin osia"? Artikkelini alussa oletin, että tavalla tai toisella "paikka" tulisi esiin sekä Virtain pelimannien puheissa että musiikissa. "Paikka" toden totta tuli esiin ohjelmistoa valittaessa, ohjelmistosta puhuttaessa ja kappaleiden nimissä. Oletuksen toiseen osaan, eli siihen, näkyykö teema myös musiikissa ja voiko sitä musiikkianalyysillä selvittää, on pakko myös vastata varovaisen myönteisesti.

Vähintäänkin 17 prosenttia pelimannien valsseista on suoranaisesti ulkomailta peräisin. Tämä ei kuitenkaan yksistään sano juuri mitään kansainvälisten ja paikallisten elementtien artikulaatiosuhteista ohjelmistossa. Pelimannit eivät itse kategorisoi valsseja "kansallissuomalaisiksi", kuten tangoa. Valsseista venäläisperäiset $(9 \%)$ koetaan ehkä jo siinä määrin "suomalaistuneiksi" ja omiksi, ettei niiden etnistä alkuperää mainita. Kaikin osin alkuperä ei edes ole yleisesti tiedossa: harvapa tietää, että esimerkiksi Elämä juoksuhaudassa on levytetty tällä nimellä ja merkinnällä "Ven. kansanlaulu" jo vuonna 1927. Alunperin venäläinen mustalaisromanssi Marusha rakennetaan "suomalaisen Matti Majan" sävellykseksi; kappale on venäläistyylinen, mutta "silti suomalainen". Sen sijaan ruotsalaiset valssit ovat Toisenlaisia, ja niitä soitettaessa muistetaan sanoa, että ne ovat "ruottalaisia". Ohjelmistossa on kuitenkin ruotsalaistyyppisiä duurivalsseja, jotka kategorisoidaan virtolaisiksi, hämäläisiksi tai vähintäänkin "soutupaikkaan" kuuluviksi.

Kaikki maailman valssit ovat kansainvälisiä - ja paikallisia. Niin on myös Muistoja Perikylästä -valssin laita. Se on heterotooppinen, mutta silti se on virtolaisista virtolaisin ja suomalaisista suomalaisin, sillä sellaiseksi se on tehty, ja siinä ominaisuudessa se esittää Perikylää ja rakentaa merkityksiä tähän paikkaan. Valssi muistuttaa läheisesti 1930-luvun suomalaisia harmonikka- ja iskelmävalsseja. Kansainväliset elementit oli jo tuolloin artikuloitu aivan omanlaiseksi suomalaiseksi kokonaisuudekseen.

Tanssia olisikin voitu tanssia Liedenpohjassa tai Perikylässä 60 vuotta sitten. Toisaalta se on juuri sellaista musiikkia, jonka säveltäjä itse määrittelee pelimannimusiikiksi ja joka sopi saumattomasti Virtain pelimannien pirtaan: valssihan oli mukana olemisen vuotenani eniten soitettu kappale. Säveltäjä Matti Tulijoelle itselleen se merkityksellistää syntymäkylää; muistot sitovat hänen menneisyyttään nykyisyyteen. Minulle tutkijana nämä merkitykset eivät avautuneet pelimannien keskusteluja kuuntelemalla, eivätkä myöskään valssin musiikkianalyyttisessa tarkastelussa. Se kertomuspolku, jota minä seurasin pitkään, liitti valssin Perinnekylään pelimannien yhtenä tukikohtana, esiintymisareenana. Tämä kertomus ei ollut henkilökohtainen, vaan se liitti koko ryhmän yhteisen kokemukset valssiin 
ja toimi näin ryhmän identiteettiä rakentavana kategorisointina.

Pelimannimusiikki ja sen esittäminen rakentaa muusikoiden identiteettiä. Se tuottaa sosiaalisuuden, ruumiillisuuden, ajan - ja paikan - kokemuksia. Nämä vuorostaan auttavat heitä sijoittamaan itsensä kulttuurisiin narratiiveihin. Populaarimusiikki täytyykin ymmärtää pikemminkin arvojen ruumiillistumana kuin edustajana tai heijastajana (Frith 1996, 117-124).

Myös Perikylän valssi ja sen esittäminen eri yhteyksissä voidaan nähdä interventiona ja todellisuutta muuttavana tekona. Virtain pelimannien musiikki ei niinkään paljasta "asioita" näistä soittajista: se auttaa heitä sijoittumaan maailmaan, luo heidän ihmisyyttään ja suhteitaan muihin ihmisiin ja paikkoihin.

\section{Lähteet}

\section{Kirjallisuus}

Asplund, Anneli 1981. Pelimannimusiikki ja uudet soittimet. Teoksessa Kansanmusiikki, toim. Anneli Asplund ja Matti Hako. Helsinki: SKS, s. 125163.

Asafjev, Boris - Glebow i.v. Tschaikowskys "Eugen Onegin". Versuch Einer Analyse des Stiles und der musikalischen Dramaturgie. Potsdam.

Biskop, Gunnel 1991. Om borgerligt valsande före 1840. Kring tiden. Meddelanden från folkkultursarkivet No 11. Svenska Litteratursällskapet i Finland: Helsingfors.

Blomster, Risto 1995. Mustalaislaulun kaksi tyyliä. Tampereen yliopisto. Etnomusikologian pro gradu -tutkielma.

Bohlman, Philip 1991. Of Yekkes and Chamber music in Israel: ethnomusicological meaning in western music history. Teoksessa Ethnomusicology and Modern Music History, toim. Blum, Stephen, Philip V. Bohlman ja Daniel M. Neuman. Urbana \& Chicago: University of Illinois Press.

Cohen, Sara 1993. Ethnography and popular music studies. Popular Music Vol. 12/2, 123-138.

Cohen, Sara 1994a. Bleeding cities, breaking bands: Paper given in the Nordic rock research network's seminar, Vig, Tanska, kesäkuu.

Cohen, Sara 1994b: Mapping the Sound: identity, place and the Liverpool sound. Teoksessa Ethnicity, Identity and Music: the Musical Construction Place, toim. Martin Stokes. Oxford: Berg.

Cohen, Sara 1995. Localizing sound: music, place and social mobility. Popular Music: Style and Identity, toim. Will Straw. Montreal: Centre for Research in Canadian Cultural Industries and Institutions, s. 61-67.

Edström, Olle 1989. Schlager $i$ Sverige 1910-1940. Göteborg: Skrifter från Musikvetenskap, Göteborgs Universitet, 21.

Featherstone, Mike 1995. Undoing Culture. Globalization, Postmodernism 
and Identity. London, Thousand Oaks, New Delhi: Sage.

Feld, Steven 1990. Sound and Sentiment. Birds, Weeping, Poetics, and Song in Kaluli Expression. Second Edition. Philadelphia: University of Pennsylvania Press.

Finnegan, Ruth 1989. The hidden musicians: music-making in an English town. Cambridge: Cambridge University Press.

Foucault, Michel 1986. (1984) Of Other Spaces. Transl Jay Miskowiec. Diacritics. A review of contemporary criticism. Spring 1986, vol 16, number 1.

Friedman, Jonathan 1994. Cultural Identity and Global Process. London: Sage.

Frith, Simon 1996. Music and Identity. Teoksessa Questions of Cultural Identity, toim. Stuart Hall \& Paul du Gay. London, Thousand Oaks, New Delhi: Sage.

Grenier, Line 1990. The Construction of Music as a Social Phenomenon: Implications for Deconstruction. Canadian Music Review, Vol. 10, no. 2: 27-47.

Grossberg, Lawrence 1996. Identity and Cultural Studies - Is That All There Is? Teoksessa Questions of Cultural Identity, toim. Stuart Hall \& Paul du Gay. London, Thousand Oaks, New Delhi: Sage.

Harvey, David 1989. The Condition of Postmodernity. An Enquiry into the Origins of Cultural Change. Oxford: Basil Blackwell.

Hoppu, Petri 1995. Peilisaleista riihitansseihin. Uudenkaarlepyyn seudun menuetti 1700-luvulta nykyaikaan. Tampereen yliopisto. Etnomusikologian pro gradu -tutkielma.

Jalkanen, Pekka 1989. Alaska, Bombay ja Billy Boy. Jazzkulttuurin murros Helsingissä 1920-luvulla. Helsinki: Suomen etnomusikologisen seuran julkaisuja 2.

Jalkanen, Pekka 1992. Valssi-hakusana. Suuri Musiikkitietosanakirja. Helsinki: Weilin \& Göös.

Järviluoma, Helmi 1986. Philip Taggin aksiomaattisen kolmikon, erityisesti sen kansanmusiikkikategorian arviointia ylivieskalaisen musiikkiaineiston valossa - Helmi Järviluoma: Musiikki, liikkeet, hillikkeet. Tampere: Kansanperinteen laitoksen moniste 11, s. 151-162.

Järviluoma, Helmi 1989. "Kiitos rehtori, taas palaa koululla valot." Pelimannimusiikin elvyttäminen Virroilla 1970-luvulla. Teoksessa Soivat Virrat, toim. Päivikki Suojanen. Tampere: Kansanperinteen laitos M 14.

Järviluoma, Helmi 1990. Kansanmusiikkiliikkeen elementit katosta lattiaan. Tiede ja edistys 1.

Järviluoma, Helmi 1991. Kentän paikallinen tuottaminen: 'tutkijan' ja 'pelimannien' kategoriatyöskentelyn analyysia. Sosiaalisia käytäntöjä tutkimassa. Katkelmia empiiri-sen tutkimuksen vaiheista. Tampere: TaY sos.pol.laitoksen julkaisu A:1 (toim. Forsberg, Jokinen, Juhila, Järviluoma et.al.). 
Järviluoma, Helmi 1995a. Local Construction of Identity: Analysing Categorywork of an Amateur Music Group. Teoksessa Popular Music: Style and Identity, toim. Will Straw. Montreal: Centre for Research in Canadian Cultural Industries and Institutions, 155-161.

Järviluoma, Helmi 1995b. Johdanto: Paikkoja, musiikkeja, identiteettejä. Teoksessa Musiikkimaailmoja ja äänimaisemia. Virtain kuulokulma, Helmi Järviluoma (toim.). Tampere: Virtain tutkimuksia 13, Kansanperinteen laitos J21, s. 1-20.

Järviluoma, Helmi 1996. Nuoret äänimaisemoijina: paikan ja tilan äänellisestä tuottamisesta. Teoksessa Näin nuoret. Näkökulmia nuoruuden kulttuureihin, toim. Leena Suurpää ja Pia Aaltojärvi. Helsinki: SKS, s. 204-229. Kolehmainen, Ilkka (toim.)1975. Vanhoja pelimannisävelmiä. Helsinki: SKS. Alunp. Suomen kansan sävelmiä III. Kansantansseja (1893-97) (toim. Ilmari Krohn).

Kolehmainen, Ilkka 1978. Kansantanssi, Suomi -hakusana. Otavan Iso Musiikki-tietosanakirja.

Kurikka, Kaisa 1995. "Sitä kuusta kuuleminen..." Kodin ikävä Irmari Rantamalan teoksessa Harhama. Teoksessa Identiteettiongelmia suomalaisessa kirjallisuudessa. Toim. Kaisa Kurikka. Turku: TY Taiteidentutkimuksen laitos A:33, 195, 35-53.

Kurkela, Vesa 1989. Musiikkifolklorismi ja järjestökulttuuri. Kansanmusiikin ideologinen ja taiteellinen hyödyntäminen suomalaisissa musiikki- ja nuorisojärjestöissä. Helsinki: Suomen etnomusikologisen seuran julkaisuja 3, 1989.

Laitinen, Heikki 1988. Mitä on paikallisuus. Musiikin Suunta 1, s. 4-21.

Laitinen, Heikki 1977: 'Kaustislaisuuden' synty.Kaustisen ensimmäiset kansanmusiikkijuhlat ja maaseutukulttuurin paluu 1960-luvun Suomessa. Suomalaisen ja vertailevan kansanrunoustieteen sivulaudaturtyö, HY, painamaton, 1977

Middleton, Richard 1992. Towards a Theory of Gesture. Teoksessa Studi e testi 1. Secondo Convegno Europeo di Analisi Musicale, ed. Rossana Dalmonte \& Mario Bavoni. Universita degli studi di Trento, pp. 345350 .

Moisala, Pirkko 1990. Muistinvaraisen musiikin kulttuurisensitiivinen analyysimetodi. Etnomusikologian vuosikirja 1989-90, toim. Vesa Kurkela ja Erkki Pekkilä. Helsinki: Suomen Etnomusikologinen Seura.

Nallinmaa, Eero 1969. Erik Ulrik Spoofin nuottikirja. Tampere.

Pekkilä, Erkki 1988. Musiikki tekstinä. Kuulonvaraisen musiikkikulttuurin analyysiteoria ja -metodi. Acta Musicologica Fennica 17. Helsinki: Suomen Musiikkitieteellinen Seura.

Rausmaa, Pirkko-Liisa 1981. Kansantanssit. Teoksessa Kansanmusiikki, toim. Anneli Asplund ja Matti Hako. Helsinki: SKS, s. 164-171.

Roivainen, Irene 1991. Kurssi kohti paikallisuutta - MCD-analyysin 
soveltamismahdollisuuksista yhdyskuntaa kuvailevan aineiston analyysissa. Sosiaalisia käytäntöjä tutkimassa. Katkelmia empiirisen tutkimuksen vaiheista. Tampere: TaY sos.pol.laitoksen julkaisu A:1 (toim. Forsberg, Jokinen, Juhila, Järviluoma et.al.), s. 152-161.

Sahlins, Marshall 1993. Goodbye to Tristes tropes: ethnography in the context of modern world history. Journal of Modern History 65, 1-25.

Slobin, Mark 1993. Subcultural Sounds. Micromusics of the West. Hanover and London: Wesleyan University Press.

Stokes, Martin (toim.) 1994. Ethnicity, Identity and Music: the Musical Construction Place. Oxford: Berg.

Suutari, Pekka 1993. Mikrotason analyysi tangon kehityksestä. Musiikkitiede 2, (1993): 43-66.

Tagg, Philip 1993. Introductory Notes to Music Semiotics. Liverpool: Institute of Popular Music. Moniste 1993.

Tamminen, Pertti 1984. Virtain museo- ja perinnetyön kokonaissuunnitelma. Moniste Pk 49.

Väänänen, Jorma 1945. Beobachtungen über Verbreitung und Art der Finnischen Volkswalzermelodien. Eine Musikwissenschaftliche Studie. Helsinki: Annales Academiae Scientiarum Fennicae, B LV, 3.

Walser, Robert 1993. Running with the Devil: Power, gender, and madness in heavy metal music. Hanover \& London: Wesleyan University Press.

Waterman, Christopher A. 1991. Jújù history: toward a theory of sociomusical practice. Teoksessa Ethnomusicology and Modern Music History, toim. Stephen Blum, Philip V. Bohlman ja Daniel M. Neuman. Urbana \& Chicago: University of Illinois Press.

\section{Painamattomat lähteet}

Laitinen, Heikki 1992. Esitelmä Kansanmusiikin tyylit -seminaarissa 30.10.1992 Kaustisella.

Westerholm, Simo 1995. Puhelinkeskustelu 15.12.1995.

\section{Nauhoitteet}

Helmi Järviluoman nauhoitukset Virtain pelimannien harjoituksissa ja esiintymisissä 1988-1993.

KPL Y = säilytteillä Tampereen yliopiston kansanperinteen laitoksen yleiskokoelmassa.

Numeroimattomat: äänittäjän hallussa.

$\mathrm{ETH}=$ viittaa Ethnograph-ohjelmalla käsiteltyjen litteraatioiden numerointiin.

Virtain pelimannien musiikkikasetti Virt-001. 


\section{Nuottiliite 1.}
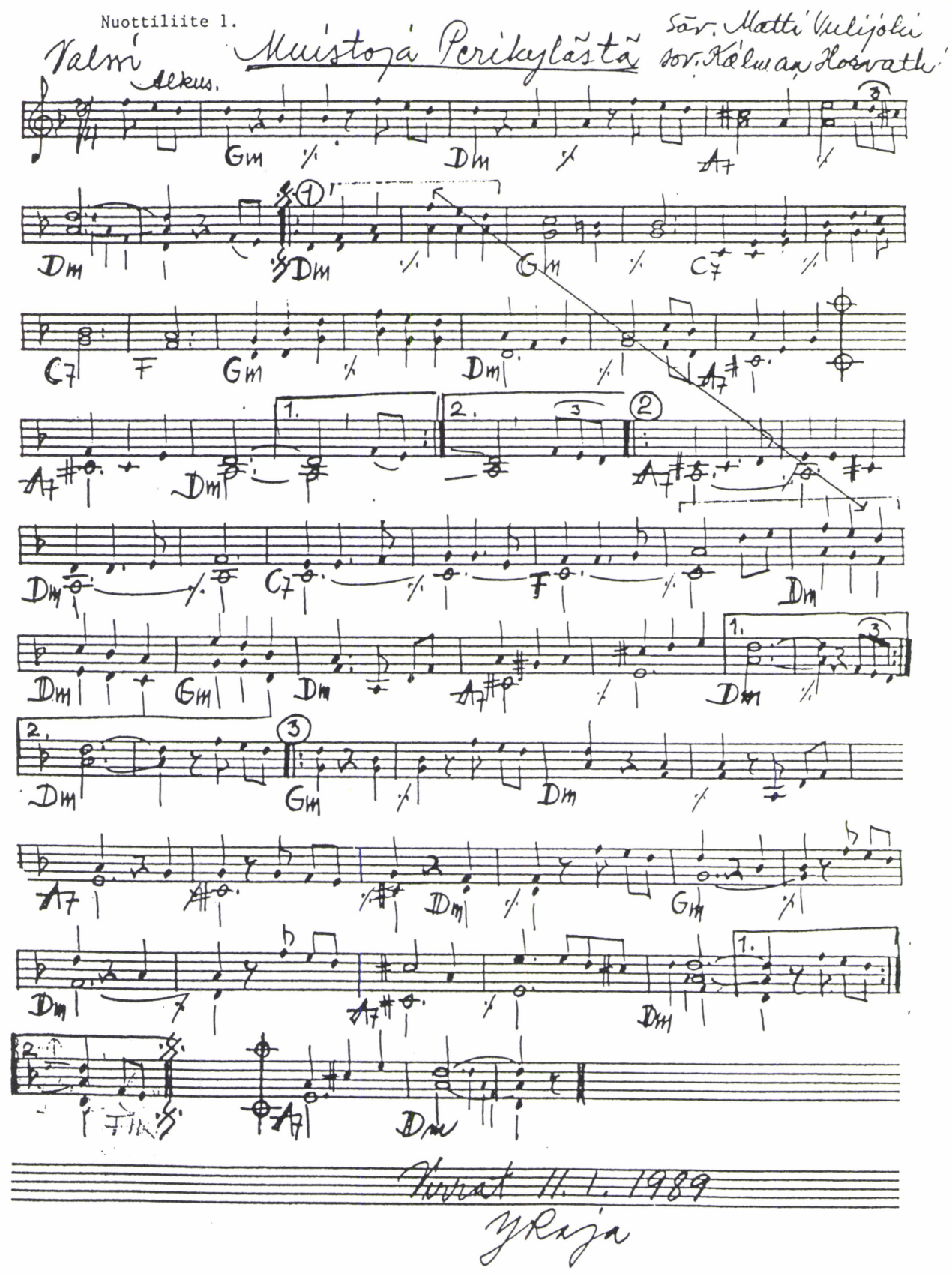


\section{Nuottiliite 2.}
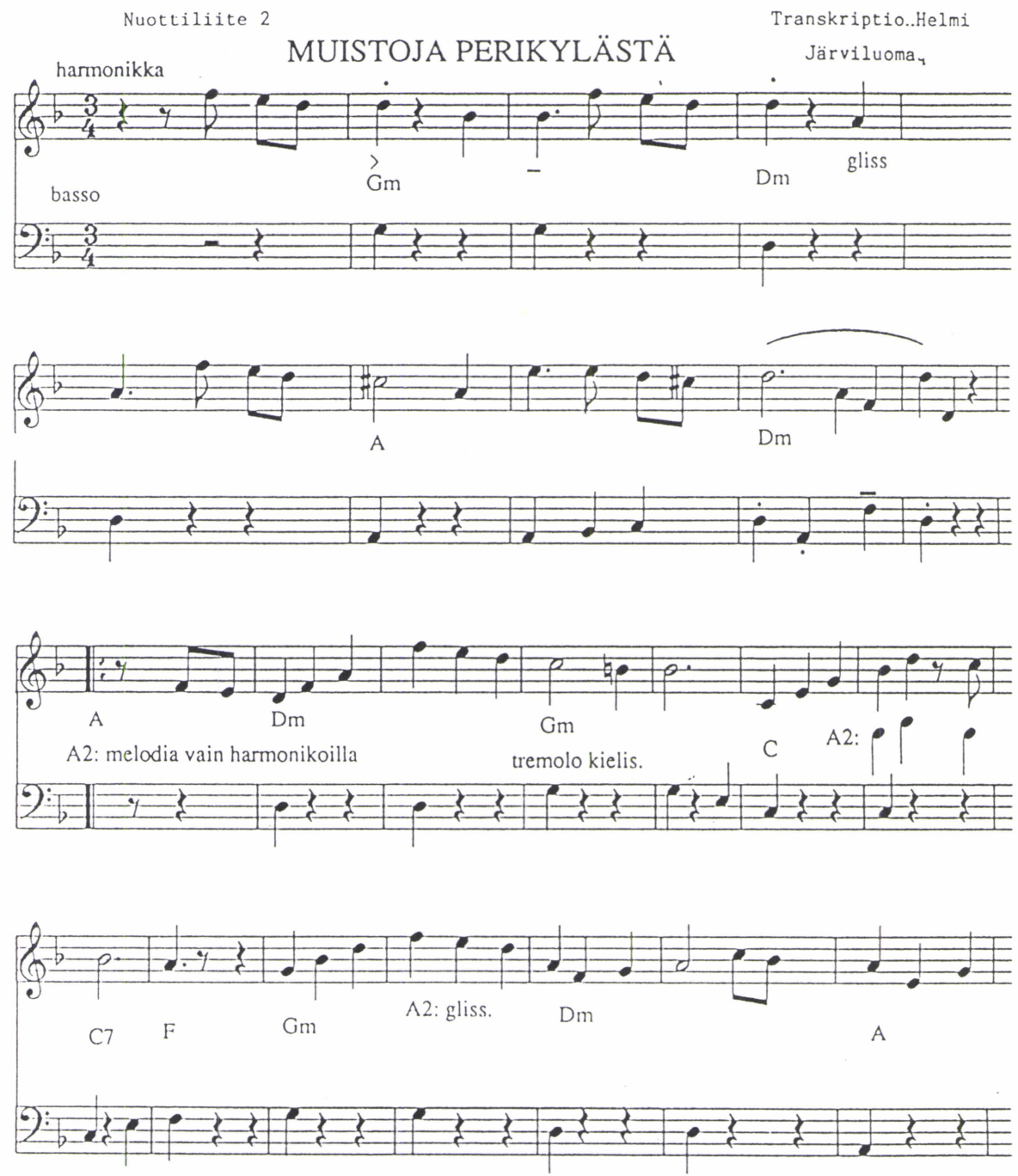

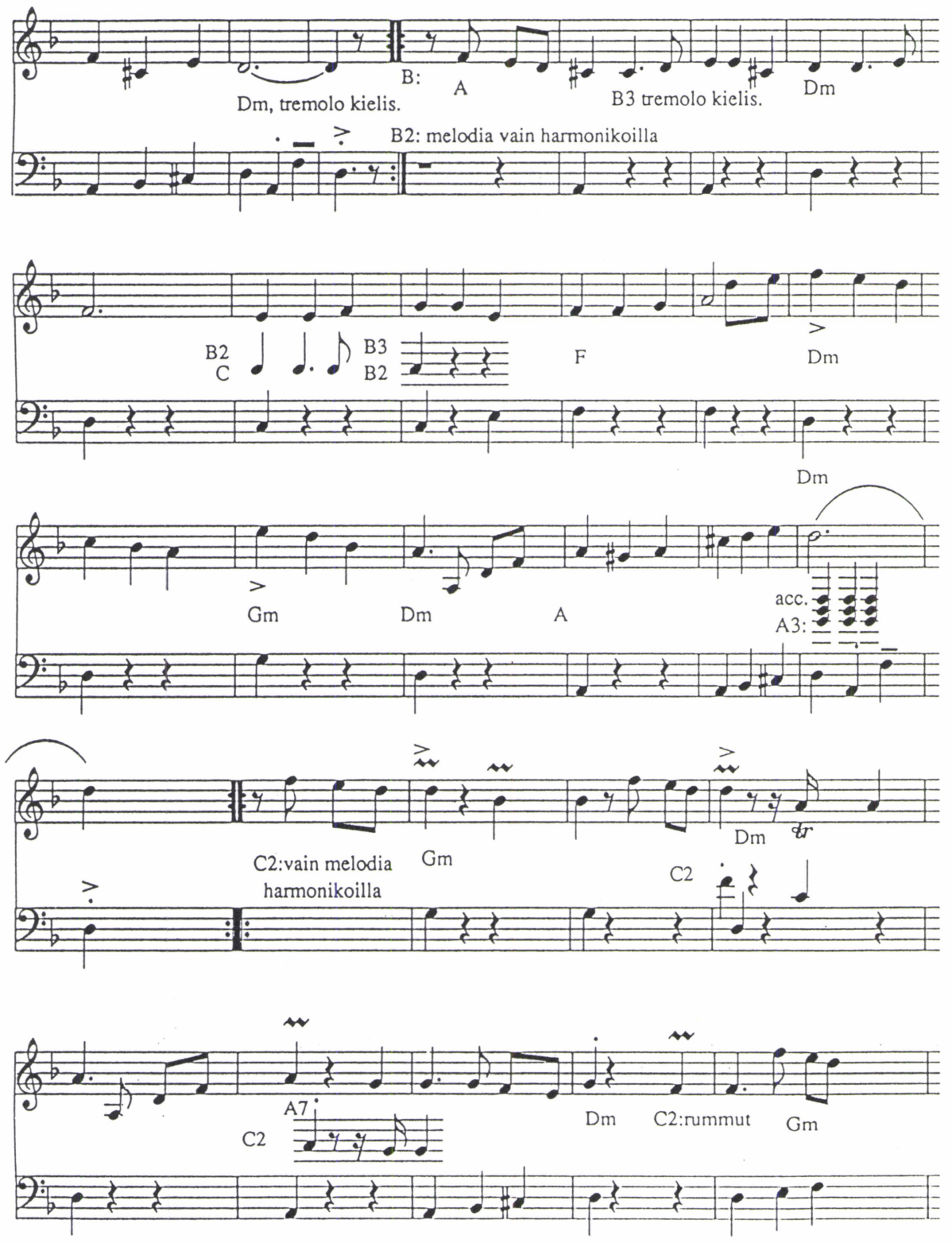
56 • Järviluoma
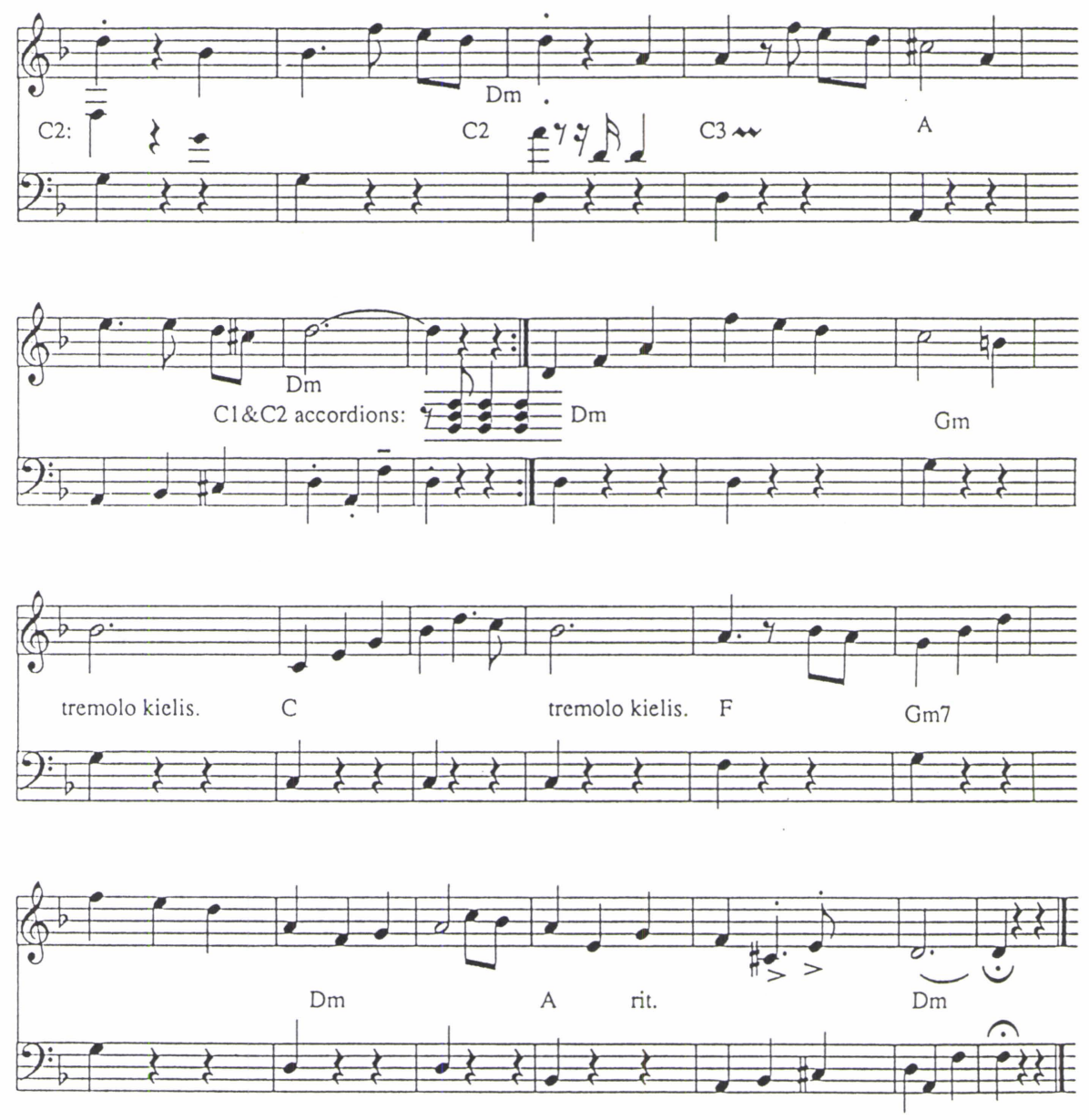
Liitetaulukko 1. Rytmimotiivit. Ohjelmistosta valitun 25 mollivalssi-nuotin rytmimotiivit, melodian iskualoista laskettuna.

Ven.=venäläiset, Engl.=englantilainen, Virt=virtolainen, Kaus=kaustislainen, UKm=uudemmat pelimannisävellykset, Isk=iskelmät, Harm=harmonikkasäveltäjien valssit. $n=$ iskualat yhteensä.

\begin{tabular}{|c|c|c|c|c|c|c|c|c|c|c|}
\hline & & Ven & Engl. & Virt. & Kaus & UKm & Isk & Harm & Perikylä & \\
\hline & $\mathbf{n}$ & 110 & 43 & 121 & 136 & 105 & 630 & 342 & 48 & \\
\hline & 1 & 28 & 60,5 & 13 & 8,8 & 24,7 & 27 & 24,7 & 12,5 & d. \\
\hline & 2 & 21 & 14,0 & 13,8 & 8,8 & 21 & 23 & 16,5 & 35,4 & d J \\
\hline & 3 & 29 & 9,3 & 25,3 & 13,1 & 19 & 20,5 & 25,2 & 4,2 & $d d$ \\
\hline & 4 & 3 & & & & 2,9 & 1,6 & 1,4 & 4,2 & 小令々 \\
\hline d & 5 & 3 & & 4 & 6,7 & 2,9 & 1,6 & 4,2 & & \\
\hline & 6 & 3 & & & & & 1 & & & \\
\hline & 7 & 3 & 4,7 & & 4,5 & & & & & \\
\hline & 8 & 1 & & & & & & 1,9 & & \\
\hline & 9 & 3,6 & 9,3 & 3,6 & 5,7 & 2,9 & 5,2 & 10,8 & 10,4 & \\
\hline & 0 & 2 & 2,3 & 2,9 & & & 2,2 & 1,9 & 4,2 & \\
\hline & 1 & & & 10,1 & 6,7 & 3,9 & 2,6 & & & \\
\hline & 2 & & & 17,1 & 2,1 & 0,9 & 6,5 & & 4,2 & \\
\hline & 3 & & & 2,9 & 1,4 & & 1,3 & & 2,1 & \\
\hline DD & 4 & & & 1,8 & & & 0,3 & & & \\
\hline & 5 & & & 6,8 & 13,9 & 6,8 & 0,9 & 4 & 12,5 & \\
\hline$a$ & 6 & 2 & & 2 & 10,5 & 8,5 & 1,7 & 1,8 & & \\
\hline 几Л+ & 7 & & & & 1,5 & & & & & \\
\hline$D \perp d$ & 8 & & & & 8,9 & & 0,6 & 1 & & \\
\hline & 9 & & & & 2,9 & & & & & \\
\hline d- हा & 0 & & & & 0,7 & & & & & \\
\hline 可的 & & & & & $2,, 9$ & 2,9 & & & & \\
\hline$\dot{I J}$ & & & & & & 3,7 & & & & \\
\hline & 3 & & & & & & & & 2,1 & $d^{\top} \alpha$ \\
\hline 14751 & $\begin{array}{l}4 \\
5\end{array}$ & & & & & & 0,3 & 1,9 & 8,3 & \\
\hline $\begin{array}{r}4 \text { गयम } \\
3 d\end{array}$ & $\begin{array}{l}5 \\
6 \\
7\end{array}$ & & & & & & & 0,2 & & \\
\hline$d 5 y$ & 8 & & & & & & & 1,2 & & \\
\hline$\xi \Omega \Pi$ & 9 & & & & & & 1 & 0,3 & & \\
\hline$\pi d$ & 0 & & & & & & 0,3 & 1,7 & & \\
\hline$d d$ & 1 & 2 & & & & & 1,7 & 0,6 & & \\
\hline d? & 2 & & & & & & 0,4 & 0,7 & & \\
\hline 5721 & 3 & 1 & & & & & 0,4 & & & \\
\hline 2535 & & & & & & & 0,5 & & & \\
\hline
\end{tabular}


Liitetaulukko 2. Virtain pelimannien ohjelmiston valssien säveltäjät, mahdolliset ensilevytysvuodet ja vuosi, jolloin otettu ohjelmistoon. Lähde: Haapanen, Suomalaisten äänitteiden luettelot ja Virtain pelimannien nuottikansio. Tarkemman analyysin kohteena olleet 25 valssia on alleviivattu.

\begin{tabular}{|c|c|c|c|}
\hline \multicolumn{4}{|c|}{ Uudemmat pelimannisävellykset } \\
\hline Valssin nimi & Säveltäjä & 1. suom. äänite & $\begin{array}{l}\text { Virt. pel. } \\
\text { ohjelmistoon }\end{array}$ \\
\hline Hervanta-päivänä & Niilo Koivisto & - & 1977 \\
\hline Hopeahäävalssi & Tellervo Haikonen & 1974, Etelä-Hämeen pelimannit & 1983 \\
\hline \multicolumn{4}{|c|}{ "Housukauppiaan valssi" Toivo Honkanen } \\
\hline Kevätsoittovalssi & Toivo Mäki & - & \\
\hline Koko kylän valssi & Pentti Peitsamo & 1974, Nokian musikantit & - \\
\hline Leppäsjärven valssi & Reino Kasittula & $\begin{array}{l}\text { 1975, Ikaalisten harmonikkamiehet } \\
\text { ia viulunelimannit }\end{array}$ & 1976 \\
\hline Metsämiehen valssii ${ }^{26}$ & Erkki Kuusela & - & 1988 \\
\hline Pakolaisvalssi & Kalle Lörpys & 1983, Kurun pelimannit & 1976 \\
\hline Pirkanmaan valssi & $\begin{array}{l}\text { N.Haapalainen, } \\
\text { sov.Irene Aittonen }\end{array}$ & - & 1988 \\
\hline
\end{tabular}

\section{Englantilainen}

Syysunelmia

Archibald Joyce

1939, Georg Malmstén ja Solistiork. -

\section{Ruotsalaiset}

Arholma-valssi

Elämää suomalais-

metsissä

Häämatka

Kerran saavun

satamaan

Kielon jäähyväiset

Koster-valssi

Lauantai-valssi

Musta Rudolf

Ruots. säv.

1964, Jorma Juselius

1988

Karl Karlsson

1944, Inga Lill Rossvald

1985

Bellman

(1961, Kalevi Korpi)

Stig Olin

1954, Olavi Virta

Lindvall

1938, Ramblers

1982

David Hellström

A. Johansson

Börje Müller

1927, Columbian soittokvintetti

1988

1936/35 Georg Malmsten ja Dallapé

\section{Venäläiset}

Elämäntoveri

Elämä juoksuhaudassa

Häävalssi

V. Salanov

1960, Georg Ots ja ork.

"ven. kansansäv."27

1927, Willy Larsen \& Stanley Lutz

Ivanovici/V.Korpela ${ }^{28}$

1938, Arvi Tikkala ja HMV-ork ${ }^{29}$

Koivu-valssi trad., sov. O. Itä

1959, Metrotytöt

Mantšurian kukku-

$\underline{\text { loilla }}$

J.A.Schatrow

1936, V. Vesterinen ja Dallapé

\footnotetext{
${ }^{26}$ Hämeen kevätsoiton yhteiskappale, Lempäälä 1988.

${ }^{27}$ Säveltäjäksi mainittu myös G. Dubriansky.

${ }^{28}$ Ivanovici oli romanialainen tsaarin armeijan kapellimestari. Suomalaisten Häävalssina tuntema sävelmä on Tonavan aallot -valssin versio.

${ }^{29}$ Kaustisen purppuripelimannit 1960, Tapio Rautavaara 1965.
} 
Marusha

Menneiltä ajoilta

Muistoja Karpaateilta

Mustanmeren valssi

Kyllikki-valssi

Valssi vanhanaikainen

\section{Virolaiset}

Saarenmaan valssi

\section{Virtolaiset}

Kesämuisto Ajosjärveltä

Mietteitä

Muistoja Perikylästä

Myötätuulessa

Ristinniemen valssi

Valssilaulu keväälle

\section{Iskelmät}

Aamu Airistolla

Akselin ja Elinan

häävalssi

Arpiset haavat

Harmaat silmät

Jääkukkia

Katja

Kauneimmat kiitokset

Kaunis on luoksesi

kaipuu

$\underline{\text { Kaunis valhe }}$

Keinumorsian

Keinussa kesällä

kerran

Koitere - Karjalan

helmi

Koivu ja tähti

Kuin lapsena ennen

Kulkurin valssi

Kultainen nuoruus

Kynttilöiden syttyessä

Laine-valssi

Lakeuden kutsu

Leila

Metsäkukkia ven.mustal.romanssi

I.Ivanovici

Ven. kansansäv.

Oskar Feltsman

Ven. kansansäv., sov. Georg Malmstén

Heikki Annala

Raimond Valgre

Jouko Lindfors

Yrjö Raja

Matti Tulijoki

Erkki Alanne

Matti Tulijoki

Erkki Alanne

Pentti Viherluoto

Heikki Aaltoila

H. Konno

Toivo Kärki

L. Lindström

Veikko Ukonniemi

Eino Partanen

Georg Malmsten

Arvo Koskimaa

Toivo Kärki

H.Jäger/M.Jäppinen

Toivo Kärki

J. Alfred Tanner

Kullervo Linna

Joe Lyons

E. Sipponen

Toivo Kärki

Georg Malmstén

kansansäv. (ven?)
1930, Heikki Tuominen ${ }^{30}$

1973

1939, V. Vesterinen ja Dallapé

1929, Ville Alanko ${ }^{31}$

1960, Leif Wager

1974

1981

1936, Georg Malmstén

1975, Solistiyhtye Imperial

1979

1957, Georg Ots ja Eestin radion viihdeorkesteri

1986

1990, Asikkalan pelimannit

1993

1985

1940-luv., A. Aimo

1968, Heikki Aaltoilan joht. ork.

1935, A. Aimo

1976

1946, Henry Theel

1932, Veli Lehto

1968, Henry Theel

1987, Jaana Hannele \& Jojo

1983

1940, A. Aimo

1987

1940, Georg Malmsten

1943, Henry Theel ${ }^{32}$

1975, Reijo Kallio

1972, Pasi Kaunisto

1932, Veli Lehto

1949, Henry Theel

1926, J. Alfred Tanner

1940-1. (Eero Väre, Olavi Virta)

1942, Harmony Sisters ja Suuri tanssi- orkesteri

1979

1975, Tumba Tamminen

1971, Pasi Kaunisto

1976

1932, Georg Malmstén ja Amarillo

1983

\footnotetext{
${ }^{30}$ Myös A. Aimo ja Dallapé-orkesteri levyttivät Marushan vuonna 1937.

${ }^{31}$ Valssin levytti vuonna 1930 myös Dallapé-orkesteri solistinaan Hannes Kettunen.

${ }^{32}$ Erkki Junkkarisen levytys 1974 revitalisoi kappaleen.
} 
Metsäpirtti

Georg Malmstén

Muisto $^{33}$

V. Korpela?

Ounasjoen rannalla [törmällä] Rauno Haahti

Pohjolan yö

Rantatie

Ruusu joka vuodesta

Saariston Sirkka

Satamista parhain

Suvimuisto

Särkynyt onni

Syksyn muistoja

Tiedä en kauniimpaa

Tunturisatu

Unteni vaalea lilja

Valkoiset kielot

Viimeinen valssi/

Muistoja Pispalasta

Viimeinen savotta

Villiruusu $^{34}$

Yölintu

$\underline{\text { Äänisen aallot }}$

\section{Kansansävelmät}

Halpa valssi ${ }^{35}$

Hangasjärven valssi

Honkamökin valssi

Hyvin vanha valssi

Joelin valssi $^{36}$

Karoliinan valssi

Kohtasen Jannen valssi

Kokin valssi

Kulkijan haave ${ }^{37}$

Koskisen Sakarin valssi

Perhos-valssi

Pääskysen valssi

Rakennusmiesten valssi Hämeestä

M. Maja

Kullervo Linna

Kaarlo Valkama

H.Sjöblom

Ilpo Mäkelä

Ikaalisista

Tampereelta

Ypäjältä

$-$

Viitasaarelta

Urjalasta

Kyröskoski
1937, G. Malmstén, Greta Pitkänen ja Dallapé

1918, Topi Aaltonen

1979, Hannu Merkku ja Seppo Leinon ork.

1953, Tapio Rautavaara

1965, Asta ja Aila \& Olavi Kivikosken yht.

1976, Pauli Räsänen

1939, Georg Malmstén ja Odeon

1950, G. Malmstén ja Nea-kvintetti 1987

1939, Eugen Malmstén ja Rytmipojat -

1930, Georg Malmstén

1966, Taisto Tammi ja Kalevi

Nyqvistin yhtye

Nacke Johansson 1977, Reijo Kallio

1940, A. Andersson

1983

1948, Olavi Virta ja Sointu-ork.

1954, Kalevi Tauru ja Triola

1979

1931, Mauno Tamminen ja Kaivohuoneen orkesteri

1981, Ilpo Mäkelän orkesteri

Evert Suonio/Sjöblom 1929, Ture Ara ja Suomi-tanssiork.

Martti Heikkilä 1942, Viljo Vesterinen ja Kristalliork.

Georg de Godzinsky 1942, Georg Malmstén

1989

Forssasta 1984, Hausjärven pel.

1980

1976

1987, Spelarit

1976

1983

1973, Ikaalisten harmonikkamiehet ja viulup.

1982

1973, Ikaalisten harmonikkamiehet ja viulup.

1983, Kankaan pelimannit

1982

1986, Ruoveden pelimannit

${ }^{33}$ Tästä suositusta valssista on tehty yli 20 levytystä.

${ }^{34}$ Villiruusu on levytetty liki kolmeenkymmeneen kertaan.

${ }^{35}$ Hämeen kevätsoiton yhteiskappale, Forssa 1980.

${ }^{36}$ Hämeen kevätsoiton yhteiskappale, Forssa 1980.

${ }^{37}$ Hämeen kevätsoiton yhteiskappale, Urjala 1984. 
Sarkin Joelin valssi

Sarvanan vaarin valssi

Tanhusikermä

-Kehruuvalssi

-Hyllytystä

Valkea ruusu, häävalssi

Valssi Kannonkoskelta

Valssi Lempäälästä

Venemiehen valssi ${ }^{38}$

\section{Kaustislaiset}

Friiti Ojalan häävalssi

Kaustisen juhlavalssi $^{39}$

Kesän tullessa

Konstan parempi valssi

Nuorison valssi

Parhaalle ystävälle
Tampereelta, sov.

Voitto Mäkelä

Kurusta

1978, Pispalan pelimannit

Ikaalisista

Erkki Ojanen

Konsta Jylhä

Konsta Jylhä

Konsta Jylhä

Konsta Jylhä

1972, Raussin pelimannit

1970, Kaustisen purppurip.

1965 , Kaustisen purppurip.

1986, Ruoveden pelimannit

1970, Kaustisen purppurip.
1974

1978

1978

1971, Ikaalisten harmonikkamiehet ja viulup.

1987, Koskelan pelimannit

1986

\section{Tunnettujen harmonikansoittajien valssit}

Ikaalisten rantatie

Ilta Syväjärvellä

$\underline{\text { Kalajoki-valssi }}$

Laura

Nuoruusmuistoja ${ }^{40}$

Ota myös syömmeni

Soittajan kaipuu

Syksyn viesti

Åsele-valssi
Unto Jutila

Veikko Ahvenainen

Unto Jutila

Wirzenius

Lasse Pihlajamaa

Onni Laihanen

Viljo Vesterinen

Seppo Leino

V. Ahvenainen
1978, Pekka Himanka

1989, Veikko Ahvenainen

1968, Pekka Himanka

1951, Vesterinen, Pihlajamaa \& Rytmi

1960, Lasse Pihlajamaa

1938, A. Aimo ja Dallapé

1953, Justeeri, Vesterinen ja Odeon -

1979 , S. Leino yhtyeineen

1978, Riihimäen harmonikkapojat

Sekalaista, kansion kohdasta "valssit"

Kesäpäivä Kangasalla

Pas d'Espagne

Sunin Åken valssi

Valssisikermä

-Nyt tuulet nuo

-On armas mulle

-Musta Rudolf
Linsén

Zahrmann

-

H.J.Fuller

?

R.Norrby
1906, Hels. torvisoittokunta

1973
1953, Kotkan lyseon kuoropojat

1950, Henry Theel

1937, Georg Malmsten

\footnotetext{
${ }^{38}$ Hämeen kevätsoiton yhteiskappale, Virrat 1989.

${ }^{39}$ Kappale voitti Kaustisen kansanmusiikkijuhlien sävellyskilpailun vuonna 1971. Simo Westerholm (puh. haast. 15.12. 1995) luonnehti kappaletta hyvin "kaustislaiseksi". Liitetaulukossa 1 kappale luokittui - alunperin vahingossa - kaustislaisten joukkoon, enkä ole poistanut sitä tästä kategoriasta.

${ }^{40}$ Hämeen kevätsoiton yhteiskappale, Hämeenkyrö 1983.
} 
Liitetaulukko 3. Muistoja Perikylästä valssin intervallien laatu.

\begin{tabular}{|c|c|c|c|c|c|}
\hline & $\mathbf{A}$ & B & $\mathbf{C}$ & yht. & $\%$ \\
\hline p & - & 6 & 12 & 18 & 14 \\
\hline p2 & 7 & 14 & 9 & 30 & 24 \\
\hline s2 & 13 & 14 & 9 & 36 & 29 \\
\hline p3 & 8 & 3 & 2 & 13 & 10 \\
\hline s3 & 5 & 1 & 4 & 10 & 8 \\
\hline $\mathrm{v} 4$ & 1 & & & 1 & 0,8 \\
\hline 4 & 2 & 4 & 1 & 7 & 6 \\
\hline 5 & & 1 & 3 & 4 & 3 \\
\hline p6 & 1 & & 1 & 2 & 2 \\
\hline s6 & & & & & \\
\hline p7 & 1 & & & 1 & 0,8 \\
\hline s7 & & & & & \\
\hline 8 & & 1 & 3 & 4 & 3 \\
\hline
\end{tabular}

